\title{
The functions of a high-frequency collocation in native and learner discourse: The case of French c'est and Swedish det är
}

\author{
INGE BARTNING AND BJÖRN HAMMARBERG
}

\begin{abstract}
This cross-linguistic study investigates the functionality and use of one particular linguistic collocation in each of two languages, viz. the French c'est and the Swedish det är, both meaning 'it is'. The data are drawn from conversational speech production by adult native speakers and second language learners. The investigation shows that these collocations are highly polyfunctional as components in different grammatical constructions, that they play a significant role as a formula in the planning and execution of utterances and that they show a characteristic distribution of frequency of use and a characteristic profile of development in learner speech. A usage-based view of how language develops in individuals is adopted in the analysis of these findings, showing that these various properties are connected to each other and that they have an important bearing on the development of learners' interlanguages.
\end{abstract}

\section{Introduction}

The role of specific high-frequency items in language use and acquisition has not yet been very much studied. However, it is becoming clear that the fact that an expression is frequently used may have important implications for the buildup of language competence. Recent research (e.g., Bybee and Hopper 2001a; Ellis 2002) has called attention to the effects that frequency of exposure and use has on the establishment of linguistic structure. According to a usage-based view of how language develops in individuals (see, e.g., Langacker 1999), the repeated use of specific linguistic items leads to their gradual entrenchment as cognitive routines in the speaker's mind.

On the other hand, frequency itself has a cause. There must be some motive or some factors causing a linguistic expression to be used with a certain degree of relative frequency. The need to communicate certain ideas, or the usefulness of putting messages in certain forms may constitute such factors. If the item in question is a grammatical construction, it may have functional 


\section{Inge Bartning and Björn Hammarberg}

qualities which motivate its being used over and over again in formulating utterances. This suggests that a study of the connections between functionality and frequency may contribute to our understanding of the process of language acquisition. The linguistic functions of high-frequency items therefore call for investigation.

We will attempt this here in exploring the functionality and use of one particular linguistic collocation in each of two languages, viz. the French c'est and the Swedish det är, both meaning 'it is'. (We will use the term 'collocation' here in a general sense, referring to a regularly occurring sequence of words.) Our data will be drawn from conversational speech production by adult native speakers and second language learners of the two languages.

Predications of the form 'it is $\mathrm{X}$ ' are very frequent in these two languages. The high frequency in spoken French of items such as c'est 'it is' and il y a 'there is/are' has been noted by several researchers (cf. Blanche-Benveniste 1990; Gadet 1989; Morel and Danon-Boileau 1998; for early French interlanguage, see Trévise 1986, Véronique 1994). In Swedish, word counts based on spoken corpora show det 'it' to be by far the most frequent word in the language and det är 'it is' the most frequent two-word combination (Allwood 1999).

A striking fact is the polyfunctional nature of French c'est and Swedish det $\ddot{a} r$. There is a high degree of parallelism between the two languages in the use of c'est and det är, as well as some interesting differences. This makes a crosslinguistic approach attractive in investigating the workings of $c^{\prime}$ 'est/det är in native and learner speech in the two languages. French and Swedish both belong to the West European typological area of place-holder languages (or languages which do not allow pro-drop, in Chomskyan terminology) (Beckman 1934; Hammarberg and Viberg 1977). This accounts for the abundant use of constructions with neutral and dummy pronouns. As we will discuss in greater detail below, French c'est and Swedish det är play a central role in structuring sentences and discourse in these languages and occur in a wide range of different contexts, in speech even more than in writing. A neutral pronoun such as French ce or Swedish det is often very useful in achieving simple reference to complex discourse entities, permitting vague or underspecified reference (cf., e.g., Fraurud 1992; Fraurud and Hellman 1999; Bartning 1997b), or serving as subject place-holders in different syntactic constructions.

The fact that c'est and det är can often be used in the initial part of sentences, as a component of a variety of constructions where they introduce sentence rhemes, makes them useful as a widely applicable formulation resource in the ongoing production of utterances. In particular, they are available to the speaker as a flexible means in the utterance-formulation process since there may be several alternative possibilities to complete the utterance after c'est/det är, and the syntactic choice of how to continue is often still open at that point. As we shall argue below, there is reason to assume that c'est and det är tend to 
work as units, i.e., as formulaic sequences with a significant role in facilitating utterance processing (cf., e.g., Wray 1999; Wray and Perkins 2000; Forsberg 2006).

Previous studies of French c'est by Bartning (1997b, 2006) and the Swedish neutral pronoun det by Hammarberg (2000) indicate that constructions with c'est/det är are also readily adopted and used by second-language learners of French and Swedish. In the present contribution we will take these studies further and compare native usage with learner production at different stages of L2 competence. We will make use of two comprehensive corpora of recorded conversations, the French InterFra Corpus (Bartning 2002) and the Swedish ASU Corpus (Hammarberg 1999). We will attempt to explore the following main questions in some detail:

(a) What is the grammatical distribution of c'est and det är in the speech of the native speakers and the learners of French and Swedish, respectively?

(b) What is the quantitative distribution of the different uses of c'est and det $\ddot{a} r$ across native and non-native speakers and across different stages of interlanguage development? In what respects do native speakers and learners converge or diverge in their ways of making use of these items? Do longitudinal profiles of acquisition appear?

(c) What role do the items c'est and det är play in the ongoing planning and execution of utterances in native speakers and learners?

\section{Some crosslinguistic remarks on the uses of c'est and det är}

Although the functions of French c'est and Swedish det är are similar to a great extent, there are also some important differences in distribution, mainly due to the different distribution of the pronominal elements, $c e$ and $d e t$.

Both French ce and Swedish det are used as third person singular pronouns, either in a referring function or as dummy pronouns forming a part of various sentence constructions. What we focus on here is the role of these forms as 'neutral' pronouns, i.e., neutralising the number and gender variation that applies to third person pronouns in other contexts. We thus concentrate on cases where ce replaces subject pronouns il/elle/ils/elles and the invariable form det replaces $d e n / d e t / d e$. A function of $c e$ and det which we will leave aside here is that of a determiner, i.e., as an article or a demonstrative.

Compared with French $c e$, Swedish det has a wider and more varied distribution. While French pronominal ce occurs only in subject position with être, or qualified by a relative clause (ce qui, ce que), Swedish det occurs in different syntactic positions, as subject, predicative, object, or governed by prepositions, and it can combine with a variety of verbs. In the role of a neutral pronoun, det acts as a counterpart not only to ce, but also to cela, ça, il (in combinations such as il est, il fait and il y a) and the object pronoun form le in certain con- 


\section{$4 \quad$ Inge Bartning and Björn Hammarberg}

texts (cf. for French, e.g., Olsson 1986; Riegel et al. 1994; Pedersen et al. 1982; for Swedish, e.g., Sundman 1980; Holmes and Hinchliffe 2003; Teleman et al. 1999; Hammarberg 2000). In the present study, we focus on a comparison of c'est/det är as the most frequent and functionally most varied collocation with the neutral pronoun $c e$ and det in French and Swedish, respectively, which means that we concentrate on the combination with the verb être/vara, restrict ourselves to the present tense, and leave out possible occurrences of the plural ce sont as well as Swedish instances of verb-subject order (är det), or intervening elements (det inte är; det kanske är etc.).

In both languages, a prominent role for c'est/det är is to introduce a predication, since in most types of constructions, c'est/det är occurs in the opening part of sentences or clauses, i.e., either in absolute initial position, or preceded, for example, by conjunctions, subjunctions, discourse particles, interjections, or a predication of saying or thinking (such as French et 'and', mais 'but', donc 'so', bon 'well', enfin 'finally', en fait 'in fact', alors 'then', ah oui 'oh yes', non 'no', je pense/trouve/crois que 'I think that'; Swedish och 'and', men 'but', så 'so', för 'for', fast 'though', att 'that', om 'if, ja 'yes/well', nej 'no', okej 'okay', jag tror/tycker 'I think'; for the use of certain discourse particles in the InterFra corpus, see Hancock 2000). Especially in French, utterances very often contain a longer opening sequence, known as the préambule (cf. Morel and Danon-Boileau 1998, Conway 2005). C'est will then occur as the introducer par excellence of the rhematic part of the utterance.

\section{Data for the present study}

\subsection{The French part}

The French data used in this study originate from interviews with Swedish learners of French of the InterFra Corpus, which was compiled in the 1990s at the Department of French and Italian, Stockholm University (Bartning 1997a). This corpus contains speech productions (interviews, picture story narrations and video film retellings) and some written material collected from Swedish learners of French at five different levels and from native students.

The InterFra Corpus contains different subcorpora of 38 university students (hence called Uni, age 19-25) (6-8 students in a longitudinal group followed during four terms, 24 in three cross-sectional groups at three university levels, 6 teacher students in a longitudinal group before and after a term abroad), 20 students at secondary school with 3,5 years of French collected on two occasions with one year's interval (hence: Sec, age 16-17), 10 beginners followed during one to two terms (collected on 5 to 10 occasions) at the university (hence: Beg, age 19-26) and, as baseline data, 20 native speakers who were exchange students at Stockholm university, mostly from northern France with standard French as their dialect (NS, age 19-25). The collected material makes a total 
of 500000 word tokens (For a later description of the corpus, see Bartning and Schlyter 2004.

For this particular study we have chosen

- first term interviews with 8 of the university students with 4,5-6 years of French at secondary school. They have already passed one month at the university and have spent 3-12 months abroad in French-speaking countries.

- first interviews with 8 of the secondary school students after 3,5 years of French at secondary school, some of them with 1-2 weeks holidays in France;

- first interviews with 8 beginners who just started (three weeks ago) a beginners' course in French at the university, with no preceding experience and no formal training of French but with 1-2 weeks of holidays in France, mostly with Swedish friends; the developmental aspects of the c'est-structures are supported by recent longitudinal data from four of the beginners in 5 consecutive interviews during their first term

- interviews with 4 of the French native speakers

The interviews have been transcribed according to standard French orthography and a key of the transcription conventions is given in the Appendix.

\subsection{The Swedish part}

The Swedish data used here are part of the ASU Corpus, which was compiled in the 1990s at the Department of Linguistics, Stockholm University. This is a text corpus of Swedish conversational speech and written essays collected from foreign and native university students in Stockholm, totalling ca 500,000 words. A full description of the corpus is given in Hammarberg (1999). For the present purpose, the oral material from six learners and six native speakers has been used.

The learner part of the corpus is longitudinally designed, recording the developing learner language from the beginner stage when the informants had just arrived in Sweden and began the university language preparatory course, to a stage where they were participating in university studies in Swedish. The part used here comprises conversational speech from two speakers each of Chinese, Greek and Portuguese, one woman and five men, aged from 19 to 23. They all had prior L2 knowledge of English and one or two more languages. These learners can be broadly characterized as a 'semi-formal', 'qualified' and 'fast' type of young adult L2 learners: 'semi-formal' since they lived at the time in the Stockholm area and received their Swedish language input partly from the course and partly from the outside environment; 'qualified' in the sense that they all had secondary education, previous experience with foreign languages, and strong instrumental motivation to learn the language of the country in order to proceed with the studies in their fields; and relatively 'fast' since they advanced from the absolute beginner stage through or close to the proficiency 
level required for university studies in about a year. The learners were recorded on ten occasions: five sessions at three week intervals between September and December 1990, four sessions at intervals of about a month from January to May 1991, and one session in March 1992. All corpus material was collected in separate sessions outside the language course and was not evaluated in the course. The oral corpus part consists of audio-taped conversations of about half an hour between one learner and one or two native speakers at a time, including different verbal activities such as interviews, discussions, picture story narrations, descriptions of objects, etc. The six learners' oral production totals ca 75,000 words, which yields a mean text length per learner of about 12,500 words.

The native part of the corpus was compiled after the completion of the learner part, to serve as target language control data. It was constructed along the same lines, except that it does not reflect a development over time. Efforts were made to make the native part as comparable as possible to the learner part, in terms of type of informants, contents and methods of data collection. Thus, a series of five half-hour sessions with similar contents was recorded with each informant. The native Swedish informants were four women and two men aged from 20 to 29 , studying various non-linguistic subjects at the undergraduate level. They spoke Central Standard Swedish as heard in the Stockholm region (although one informant, the one called Z5, had a trace of a northern accent). The six native informants spoke ca 77,000 words in total, or about 12,800 words each on average.

The learners are referred to in the corpus as C1, C2, G2, G3, Q1 and Q2 (C for L1 Chinese, G for L1 Greek, and Q for L1 Portuguese speakers). The native Swedish informants are referred to as Z1 to Z6.

The recorded dialogues have been transcribed using a modified form of standard Swedish orthography in which the common 'spoken forms' are rendered. Thus, e.g., the form de e occurs for standard written det är. A key to the transcription conventions is given in the Appendix.

\section{C'est and det är in different contexts in native and learner speech}

This section will give a comparative overview of the use of French c'est and Swedish det är by native speakers and L2 learners. We will first (in Section 4.1) establish a taxonomy of contexts for c'est and det är, which will then (in 4.2) form the basis for a quantitative account of the various uses of c'est/det är by native speakers and learners in the French and Swedish corpora.

\subsection{A taxonomy of contexts}

The various structures which involve the use of c'est/det är differ in various ways with respect to discourse function and syntactic form. For the present 
purpose, we will sort them into three groups, viz.,

(A) cases in which the pronoun (ce/det) has some kind of anaphoric or deictic reference (structures $1-11$ below);

(B) cases in which the pronoun is either non-referring or refers ahead in the utterance (structures 12-16 below); and

(C) cases in which c'est/det är is followed by some form of syntactic break (structures 17-19 below).

Before commenting on the characteristics of these main groups, we will present an inventory of structure types with selected examples from the French and Swedish corpus.

The examples are given here in the transcription in which they occur in the two corpora. Source references for the French examples are given as follows: speaker identification (group and pseudonym: Beg: Carin), task and chronological number of the task: Int(erview) 1.

Source references for the Swedish examples are given in the form of a speaker and session identification, e.g., Z4-1 for speaker Z4, session 1, C26 for speaker $\mathrm{C} 2$, session 6 . As mentioned above, $\mathrm{Z}$ refers to native Swedish informants, and C, G and Q to learners with Chinese, Greek and Portuguese, respectively, as L1. The session number for the learners (ranging from 1 to 10) gives a hint about the current stage of proficiency.

A. Anaphoric or deictic ce/det

Structure 1. C'est/det är + Noun Phrase

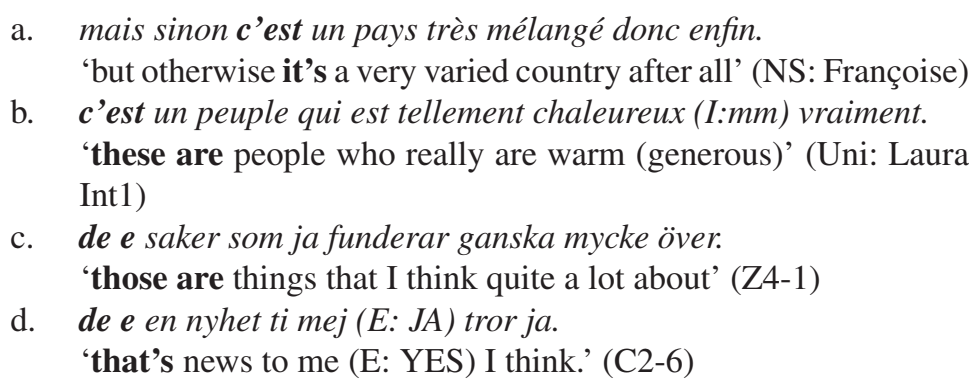

C'est/det är is followed by an NP, simple or complex, definite or indefinite, with a noun or pronominalised. French $c e$ functions as subject here. This is mostly also the case with Swedish det, although it may also occur as a preposed predicative, as in nä de e han inte 'no, (that) he is not' (Z4-3), de e $d e$ '(that/so) it is' (passim). In the quantitative tables below (Sections 4.2.1-2) we count the instances where a relative clause is embedded in the NP, as in examples (1b and $1 \mathrm{c})$, as a separate subtype. 
Structure 2. C'est/det är + Adjective Phrase

(2) a. (Topic: How to get along with Swedes compared to Brazilians) avec les Suédois c'est un peu difficile le contact [...] parfois [...] c'est plus difficile qu'avec les \# c'est pas latin [=les Suédois ne sont pas latins](RIRE) mais euh il y en a beaucoup très très gentils. (I:mm)

'it's more difficult with the \# it's (= the Swedes are) not Latin (LAUGHTER) but there are many who are very very nice' (NS: Françoise)

b. (Topic: Le Musée d'Orsay) eh c'est c'est bon mais c'est st c'est c'est grande ma je $\langle j a\rangle$. 'euh it's it's good but it's it's it's big ma I 〈ja〉' (Beg: Emelie Int1)

c. (Topic: Anthrax bacteria can remain active for years) å de e ju lite otrevligt kanske. 'and that's a bit unpleasant perhaps.' (Z1-4)

d. (Topic: How to shoot a film) $\%$ de e inte så lätt.

'\% it's not so easy.' (G2-4)

$C$ 'est/det är occurs in a clause with a predicative adjective.

Structure 3. C'est/det är + Adverbial Phrase/Prepositional Phrase
a. c'est euh en France justement. 'it's euh in France yes' (NS: Anne)
b. non pas le nom mais c'est c'est dans le même genre là. 'no not the name but it's it's of the same sort' (Uni: Marie Int1)
c. de e så himla längesen. 'it's so terribly long ago' (Z6-5)
d. de e på kvällen
'it's in the evening' (C1-3)

C'est/det är introduces an adverbial of place, time, manner etc., which can also have the form of a prepositional phrase.

Structure 4. C'est/det är + Infinitive Phrase
a. I: quel est ton loisir préféré? $\mathrm{E}$ : je crois que c'est lire.
'what is your preferred leasure time occupation? I think that it's to read' (Uni: Lena Int1)
b. non c'est eh li eh lire eh c'est 〈lättare〉.
'no it's eh li eh read eh it's easier' (Beg: Jan Int2) 
c. nu finns de ju nästan bara en väg ut. å de e ju å anfalla.

'now there's almost only one way out, y'know. and that's to attack.' (Z2-3)

d. (Topic: Whether the informant experiences difficulties in writing Swedish)

... för ja läser teknik. (B: JA) så de e bara lösa problem. (B: JAHA MH) s- man behöver inte skriva uppsats.

'... because I study technology. (B: YES) so it's only [to] solve problems. (B: YEAH WELL) s- you needn't write essays' (C210)

C'est/det är is followed by an infinitive phrase. No instances occur with the native French speakers; it seems that French speakers would tend to choose other formulations here in oral language (cf. however some literary examples in Olsson 1986: 137: C'est insulter la Fortune que de ne pas y croire (Sagan)). Native Swedish examples (like (4c)) are few but normal for standard spoken Swedish. Examples like (4a), (4b) and (4d) suggest that this construction may be used by learners as a simplified structure, avoiding a more cumbersome, careful formulation.

Structure 5. C'est/det är + Subclause
a. c'est parce que j'ai trouvé qu'il y avait un côté comment dire.
'it's because I've found that there was something how to say' (NS: Anne)
b. oui mais c'est parce que je ne peux pas rouler les + les $+r$. 'yes but it's because I can't pronounce the the -r' (Uni: Laura Int1)
c. de e ju bara va ja tror att de heter.
'it's only what I think it's called' (Z2-5)
d. de har ett hål. - - - de e för att man kan hänga de på en krok
'it has a hole. - - - it's so that you can hang it on a hook' (Q1-7)

The subclause may be introduced by all sorts of subjunctions. In the French corpus a very frequent one is parce que, which has been found to be an overused connector in learner discourse (statistically significant, Hancock 2000).

Structure 6. Det är + Stranded Preposition (only in Swedish)

$$
\begin{aligned}
& \text { de e ja helt övertygad om. } \\
& \text { 'that I'm quite convinced about' (Z1-3) }
\end{aligned}
$$

An anaphoric pronoun governed by a preposition is fronted, leaving the preposition stranded. The Swedish Verb-second constraint accounts for the word order det är in such cases. The initial placement (topicalisation) of a non-subject 


\section{Inge Bartning and Björn Hammarberg}

pronoun is considerably more frequent in Swedish than, e.g., in English with its stricter adherence to SVO order.

Stranded preposition constructions do not occur in French.

Structure 7. 'Tough' construction (c'est/det är + Adjective + Infinitive Complement)

a. (Topic: Racism in France)

peut-être que je ressens pas [...] c'est difficile à percevoir.

'maybe that I don't feel [...] it's difficult to perceive' (NS: Françoise)

b. (Topic: Discussion of musical genres)

c'est difficile à expliquer SIM (SIGH).

'it's difficult to explain' (Sec: Tomas Int1)

c. (Topic: What is going on in a picture)

de e hemskt svårt å säja.

'it's terribly difficult to tell' (Z5-5)

d. (Topic: Describing a handle)

de e lätt att = att hålla.

'it's easy to = to hold.' (Q1-6)

This is the use of celdet in the so-called 'tough' construction, which has been analysed as the raising to subject of an object of an infinitive phrase (see for French Pedersen et al. 1982: 325; for Swedish Sundman 1987: $114 \mathrm{ff}$.); for example in (7a): (i) percevoir cela est difficile $\rightarrow$ (ii) c'/cela/ceci est difficile à percevoir; (7c): (i) å säja de e hemskt svårt $\rightarrow$ (ii) de e hemskt svårt å säja. In the resulting construction the infinitive functions as a complement to the adjective: difficile à percevoir; svårt å säja. The infinitive then specifies the respect in which the adjective is relevant. This construction is possible with a certain set of adjectives. The majority of instances in our corpora, both from native speakers and learners in both languages, contain the adjective 'difficult': c'est difficile à ... / de e svårt å ....

We have chosen to categorise these cases separately from the 'c'est/det $\ddot{a} r+$ AdjP' cases in 2 above. In the French corpus there are very few examples of this type both in NS and in NNS production.

Structure 8. Object det raised from Subclause position (only in Swedish)

$$
\begin{aligned}
& \text { de e ja inte säker på att afrikanerna tycker } \\
& \text { 'that I'm not sure that the Africans think' } \\
& \text { (= 'I'm not sure that the Africans think so') (Z4-1) }
\end{aligned}
$$

A fronted object pronoun in combination with the Verb-second constraint causes the word order det är. Cf. the comment on Structure type 6 above. An analogous construction with c'est does not occur in French. 
Structure 9. C'est/det är with Left Dislocation
a. (Topic: Comparison between Swedish and French salaries) la moyenne euh des salaires c'est plus élevé que \# les gens vivent mieux en général.
'the mean salary euh it's higher than \# people have a better living in general' (NS: Françoise)
b. et euh mon âge c'est dix-neuf NON c'est vingt maintenant (RIRE). 'my age it's nineteen no it's twenty now' (Uni: Eva Int1)
c. astrologi de e ju en ny ny sorts religion eller va man ska säja. 'astrology that's a new new sort of religion or what you may call it' (Z2-5)
d. femti år de e inte så kul att fylla. 'fifty years that's not so fun to become' (Q1-7)

In both languages, left-dislocated structures with c'est/det är are quite frequent in colloquial speech. A thematic element of the sentence has been extracted to the left and is resumed by the pronoun ce/det. This dislocated element may be an NP, an infinitive, or a PP which occurs in direct connection with the following rhematic part introduced by c'est/det är. Especially in French, but sometimes also in Swedish, the left-dislocated part may contain more than one constituent; this is known in French grammar as a préambule (Morel and Danon-Boileau 1998; Conway 2005).

The part of the sentence which is introduced by c'est/det är coincides in form with a corresponding structure type under 1 to 8 above. However, we count the sentences with left dislocation here as a separate structure type.

Structure 10. C'est/det är in Pseudo-Cleft construction

a. (Topic: Sweden)

ce que j'aime bien ici c'est que les gens sont tous en haut.

'what I like here that's that people are all at the top.' (NS: Françoise)

b. ce ce qui me manque c'est que je je n'ai pas été en France pendant deux ans.

'what I miss is that's that I havn't been in France for two years' (Uni:Lena Int3)

c. de som e svårast å måla de e typ ansikten å händer å sånt. 'what's most difficult to paint that's like faces and hands and such.' (Z4-4)

d. (Topic: The meaning of the notion "idiot" in Greek) de som inte e sta-statligt eller offentligt de e idiotiskt. 'what isn't gov- governmental or public that's idiotic.' (G3-10) 


\section{Inge Bartning and Björn Hammarberg}

We gather here pseudo-cleft sentences with a resumptive ce/det, which is a characteristic feature that makes this variant of pseudo-cleft a distinctive structure-type in French and Swedish. Actually, this is a special case of left dislocation, akin to our Category 9 above, in which the dislocated part consists of a pronoun modified by a relative clause (French ce que $X$; ce qui $X$; Swedish det som $X$; vad som $X$ ). The first element of the sentence is thus a periphrastic relative and the second, introduced by c'est/det är, is a sequence (NP, infinitive, that-clause) which maintains a complement relation with the verb of the relative (see Riegel et al. 1994: 432-433).

Pseudo-cleft sentences with a resumptive ce/det are characteristic of colloquial spoken French and Swedish. Sentences like (10a-d) would also be possible (although probably less frequent) without a resumptive pronoun: ce qui me manque est $X$; de som e svårast å måla $\boldsymbol{e} X$. That variant, however, falls outside the scope of the present study.

Structure 11. Det är in terminal position in Subclause
a. $\quad$ nu kan man till å me se hur långt de e / tjugi centimeter långt. 'now you can even see how long it is / twenty centimetres long.' (Z3-4)
b. ja vet inte riktigt hur lång tid de e. 'I don't quite know how long time it is.' (Q2-10)
c. bon c'est des bien grands mots pour ce que c'est mais 'well that's pretty big words for what it is but' (NS: Mélanie)

Here c'est/det är occurs in a subordinate clause. Unlike the other structure types in this taxonomy, c'est/det är does not function here as an introducer of a predication, but occurs toward the end of the sentence, to complete an ongoing utterance which is usually already planned in final shape by the speaker at this stage.

In our French corpus we have only occasional examples of Structure 11, such as (11c).

\section{B. Non-referring or cataphoric ce/det}

\section{Structure 12. Impersonal}

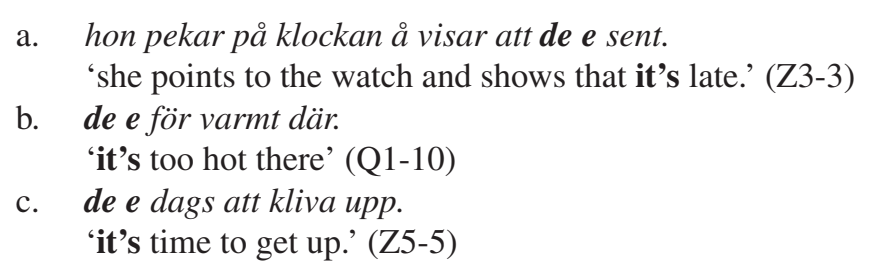




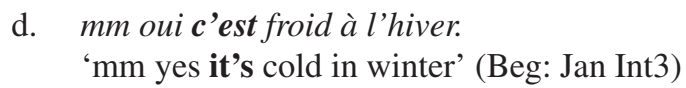

In Swedish, a non-referring neutral det is required as a dummy subject pronoun with impersonal predicates of various types (cf. Teleman et al. 1999: Vol. 4, $58 \mathrm{ff}$.). Many different verbs are used with impersonal det. Det är occurs with adjectives (12a-b), participles or adverbials (e.g., dags in (12c)).

In standard French, impersonal il est, il fait are used in corresponding constructions, e.g., il est tard 'it is late', il fait froid 'it is cold'. We have, however, also found c'est used in this function by early learners in our corpus, as in (12d).

Structure 13. Existential

\footnotetext{
a. de e ju fortfarande barn som blir misshandlade 'there are still children who get maltreated' (Z2-4)

b. de e skillnader mellan generation. 'there are differences between generations.' (C1-10)

c. I: il y a combien de pièces? une pièce? deux pièces? E: oui. c'est // eh quatre pièces. 'there are // euh four rooms' (Beg: Jan Int4)

d. mais ça dépend si c'est quelque chose qui m'intéresse. 'but that depends if there's something that interests me' (Uni: Yvo Int1)
}

Swedish det is used as a dummy subject in existential sentences. These are the cases where English uses there. In these cases, standard French uses constructions with il: il y $a$ 'there is/are'. However, the InterFra corpus evidences a typical learner use of c'est for $i l y$ a from the early stages to more advanced, as in $(13 \mathrm{c}-\mathrm{d})$. It is interesting to note that il y a emerges later than $c^{\prime}$ est in the early stages of the InterFra corpus.

Sundman (1980), in her investigation of Swedish existential sentences and related constructions, lists the following formal criteria for identifying the existential construction: (i) A dummy det in subject position, (ii) an NP as logical subject, (iii) no predicative. She also points out (1980: $19 \mathrm{f}$.) that the logical subject occurs in object position, that the logical subject is indefinite, that the logical subject can in most cases replace det, and that a place adverb här, där 'here', 'there' can sometimes serve instead of a dummy subject as placeholder.

The function of this construction type is to express the logical subject as rhematic. It is typically used to introduce new referents in the discourse (Ekerot 1979: $96 \mathrm{f}$.). If the logical subject includes a relative clause, as in (13a), this contains new information. This distinguishes this type from the cleft construction which we categorise as Type 16 below. Instances where the logical subject 


\section{Inge Bartning and Björn Hammarberg}

includes a relative clause, such as (13a and $13 \mathrm{~d})$, are counted as a separate subtype 13:2 in the quantitative tables below.

Structure 14. Anticipating

a. pour un noir ou un magrhebin c'est beaucoup plus difficile de s'intégrer.

'for someone from the Maghreb it's more difficult to get integrated' (NS: Anne)

b. parce que c'est pas naturel de parler en classe je pense.

' 'cause it's not natural to speak in class I think.' (Uni: Yvonne Int1)

c. de e klart att de e bra å kunna andra språk också.

'of course it's good to know other languages as well.' (Z3-5)

d. för de de e viktigt hur man presentera ett projekt

' 'cause it's important how you present a project' (Q1-10)

In this type of construction c'est/det är is followed by a predicative adjective, and ce/det anticipates an extraposed constituent which constitutes the logical subject of the sentence. The extraposed constituent may have the form of an infinitive or a clause.

The extraposed constituent can replace ce/det; cf. (14b) Parler en classe n'est pas naturel. In written French the use of $c e$ is often replaced by $i l: C$ ' $/ i l$ est permis de fumer 'It is allowed to smoke'.

Celdet functions like a cataphoric pronoun in these structures (in contrast to the ce/det in structure Types 4 and 5 above) in that it anticipates the extraposed logical subject. However, in this role it acts as a dummy, or expletive subject and is mostly discussed in these terms in the grammatical literature.

\section{Structure 15. Right dislocation}

a. c'est trois ans la licence.

'it's (= it takes) three years the bachelor's degree' (NS: Mélanie)

b. je trouve que c'est beaucoup plus intéressant la le province.

'I think that it's much more interesting the countryside' (Uni: Yvonne Int1)

c. de e ju så himla omfattande de där.

'it's so awfully big that' (= it's such an awfully big question, that') (Z6-5)

d. ja tycker de e så sjukt just de här att dom tillverkar ruskia vapen 'I think it's so sick just the fact that they produce horrible weapons' (Z3-3) 
The subject of a predicative sentence has been extracted to the right and is replaced in its canonical position by ce/det. Whereas French uses the neutral ce invariably in this case, the Swedish pronoun has to agree in number and gender with a dislocated noun, which causes det to alternate with other forms, e.g., den är fin, den här tavlan 'it's fine, this picture' (Singular Uter).

\section{Structure 16. Cleft}
a. (Topic: Socially obedient)
je trouve que les Suédois sont beaucoup plus ou c'est peut-être les Français qui le sont beaucoup moins (RIRE).
'I think that Swedes are much more or it's maybe the French who are so to a lesser extent' (NS: Anne)
b. c'est pas moi qui va investir.
'It's not me who will make an investment' (Uni: Sabina Int1)
c. de e i köket man använder den.
'it's in the kitchen you use it' (Z1-2)
d. ja ja kan tänka mej att de e därför som han fortfarande lever. 'well I can imagine that it's therefore that (= that's why) he is still alive' (Z1-3)

French and Swedish use ce and det, respectively, as dummy pronouns in the cleft construction. The usual type of cleft sentences in French and Swedish has the form $c^{\prime}$ est/det är + NP/Adv/PP/V + Relative clause. French and Swedish clefts are formed (like clefts in English) by extracting a constituent from the uncleft sentence, introducing it by c'est/det är, and turning the remaining part of the sentence into a relative clause, e.g.,

$$
\begin{aligned}
& \text { j'aime Nicolas } \rightarrow \text { c'est Nicolas que j'aime } \\
& \text { 'I love Nicolas } \rightarrow \text { it's Nicolas that I like' }
\end{aligned}
$$

Cleft sentences usually function as emphatic structures, emphasising the element introduced by c'est/det är. In Swedish, this construction may in some cases coincide syntactically with existential sentences containing a relative clause (cf. Sundman 1980: 54 ff.). Thus, e.g., a sentence like (13a) above, if read in isolation, has two readings:

( $\alpha) \quad$ de e ju fortfarande barn som blir misshandlade 'there are (= exist) still children who get maltreated' (Type 13: existential)

(ß) de e ju fortfarande barn som blir misshandlade

'it's still children (= children are still the ones) who get maltreated' (Type 16: emphatic cleft) 
In $(\beta)$, unlike $(\alpha)$, the relative clause is thematic and contains known information, and the sentence prosody differs, placing emphatic stress on barn. While the rhematic constituent is always indefinite in Type $(\alpha)$, it may be definite or indefinite in the emphatic clefts of Type ( $\beta$ ).

In standard French, c'est is used in Type ( $\beta$ ) and il y a in Type ( $\alpha$ ); however, as we showed in (13d) above, we have found occasional instances where the Swedish learners of French have extended the use of c'est to the existential function.

\section{Formulation breaks}

Breaks in the fluent formulation of the utterance are a natural part of the production of utterances. This is typical of impromptu speech, which is by definition spontaneous and not always fully planned before execution in a typical conversational situation. Such breaks may affect the syntactic structure of the sentence in various ways.

Our concern here are breaks which occur after c'est/det är, which is a point in the ongoing utterance where breaks typically tend to occur. In Swedish, det $\ddot{a} r$ is often followed by an unstressed modal adverb, such as $j u$ 'you know', $v \ddot{a l}$ 'isn't it', or the negation inte 'not' etc. in the same prosodic unit before a break. In French, too, c'est is occasionally followed by the negation pas before a break. These cases are also included here. Taking into consideration what follows after the break, we distinguish cases of repetition, reformulation and abandonment, types which range from slight to more radical alteration of the current utterance. These phenomena offer some insight into the utteranceproduction process in that they bear witness of points of hesitation or replanning. The mere occurrence of a pause, filled or unfilled, at the location after c'est/det är (+ModAdv) has not been counted, however, although this is also clearly a hesitation phenomenon. It seems that the places in the utterance where pauses occur tend to vary much more and are not quite so typically connected with the item c'est/det är.

\section{Structure 17. C'est/det är repeated}

a. mais bon c'est c'est c'est intéressant parce que c'est assez assez complet en marketing.

'but well it's it's it's interesting because it's rather rather complete in marketing' (NS: Françoise)

b. ehc'est c'est bon mais c'est c'est c'est grande ma je $\langle j a\rangle$. 'euh it's it's good but it's it's it's big ma I 〈ja〉' (Beg: Emelie Int1) 
c. $\quad$ ja de e ju = de e ju ganska självklart $i$ såna situationer på nå sätt.

'well it's = it's rather self-evident in such situations in a way isn't it' (Z1-4)

d. nej de e de e bra att åka bort tycker ja.

'no it's it's good to go away I think.' (Q1-10)

C'est/det är (+ModAdv) is repeated (with or without an intervening pause) before the utterance is continued. The break can be interpreted as a moment of continued planning of a not yet fully planned utterance. Although no reformulation is observable in the uttered sentence in this case, some latent change of utterance plan may of course have taken place. Note that it is the fragment before the break that is counted here; the post-break part starting with c'est/det $\ddot{a} r$ is categorised separately in the appropriate category under A or B above.

Structure 18. C'est/det är + reformulation

a. je veux dire c'est / \# j'ai vu en en séminaire. 'let's say it's / \# I saw at the seminar' (NS: Mélanie)

b. eh c'est pas \#eh mon eh st (instrument〉 est [...] 'it's not \# my instrument is [...]' (Beg: Jan Int4)

c. ja tycker att de e / på nå sätt / ur moralisk synvinkel så e de väl ganska så förkastligt

'I think that it's / in a way / from a moral point of view it's rather reprehensible isn't it' (Z1-3)

d. $\quad$ så / = ja de e / ibland $=e$ de = orättvist tror ja.

'so / = well it's / sometimes = it's = unfair I think.' (C2-9)

In this case a restructuring of the ongoing utterance is obvious. (The restructuring breaks are rendered by "\#” in the French and "/" in the Swedish transcripts.)

Structure 19. C'est/det är + abandonment

a. et le club à cinquante SIM cinquante couronnes là c'est 'and the club (which costs) fifty SIM fifty crowns you know it's (NS: PN)

b. mais en classe quand on va demander quelque chose tout le monde demande en suédois + et pour moi c'est

'but in class when you ask something everybody asks in Swedish and for me it's' (Uni: Yvonne Int1)

c. ja. de beror ju på / man kan ju argumentera för å emot i dom flesta frågor så att de e I

'well. it depends / of course you can argue for and against in most issues so that it's /' (Z1-4) 
d. ja dom bara gå hemifrån å låter alla ljus på. å (B: JA) de e / 'yes they only go from home and leave all lights on. and (B: YES) it's /' (Q1-9)

Here c'est/det är (+ ModAdv) occurs in a position to introduce a predication, but the continuation is abandoned. The speaker starts an utterance with the common introducer c'est/det är, but fails to produce either a relevant message or its appropriate formulation. Nor is the utterance recast, as in Type 18 above; the fragment $c^{\prime}$ est/det $\ddot{a} r$ is left hanging. In many instances, this c'est/det är will serve as a turn-ending signal.

In summary, this taxonomy of contexts shows that French c'est and Swedish det $\ddot{a} r$ can participate in a wide range of different sentence structures in the respective language, especially in the function of introducing a predication. As we have seen, most of these various structures are produced by both native speakers and learners.

In the structures under $\mathrm{A}$ above (Structures 1-11), the pronoun refers to something given in the preceding discourse or in the situation. Especially the fact that the neutral pronoun can make simple reference to complex contents without unnecessary explicitness makes it widely useful in communication. One may expect that second language learners, once they discover this convenient mechanism in the language, are ready to use it freely and perhaps overuse it in a simplifying way in their attempts to express themselves in conversation.

The establishing of anaphoric reference in discourse has been discussed by several authors from a point of view which may help elucidate this function of the neutral pronoun. In general, we adopt the view of Brown and Yule (1983: $206 \mathrm{ff}$.) that the role of reference is to establish an entity in the speaker's and hearer's mental 'discourse representation' (or 'discourse model'). The entity, or referent, may be some object which is represented by an antecedent noun, or it may be an event, a fact or a proposition, or some more complex information derivable from the foregoing discourse (Fraurud 1992). Following Fraurud and Hellman (1999), anaphora can be seen as "the retrieval of a discourse referent established into a (mental or computational) discourse model by means of a preceding expression" (Fraurud and Hellman 1999, italics in original). In some cases the referent is explicitly identified by, e.g., an antecedent noun, an infinitive phrase or a sentence. In other cases, the information referred to is not signalled explicitly in the preceding discourse, but has to be inferred when it is brought to attention by the anaphoric pronoun. That is, something in the discourse is established as an entity only when referred to by an anaphor. According to Fraurud and Hellman, this "involves hypostatization, the process by which something which is not an entity comes to be treated like an entity, resulting in what we here call hypostatized discourse referents" (Fraurud and 
Hellman 1999, italics in original). A characteristic use of the neutral pronoun ce/det is to function as a hypostatization anaphor (term after Fraurud 2000) to establish mental representations of complex hypostatized entities from the preceeding discourse. Consider Example (20) from the native Swedish informant $\mathrm{Z} 2$ :

(20) (Topic: Watching a picture of an African storyteller in a group of listening people)

E: va får du för associationer när du ser den där bilden? du kanske tänker på paralleller.

'what associations do you get when you see that picture? You may perhaps think of parallels.'

I: en dagisgrupp tänker ja på.

'I think of a kindergarten group.'

E: jaha. 'oh.'

I: de e dom enda tillfällena tycker ja som som man samlar en grupp människor å berättar en historia.

'those are the only occasions I think when you gather a group of people and tell a story.' (Z2-5)

Here, de relates to the foregoing dagisgrupp 'kindergarten group', but does not refer to this type of group as such. Rather, the event or occasion when such a group is assembled is hypostatized as a referent. By connecting de to tillfällena 'occasions' in the sentence that follows, the speaker makes this intended reference more explicit and accessible to the listener.

An important feature with anaphoric reference is that it may be more or less heavily underspecified, i.e., the entity referred to may be only vaguely identified by the anaphor. Underspecified reference is successful if the listener obtains a discourse representation which matches that of the speaker sufficiently well. This possibility of varying and reducing the precision of reference is clearly a useful mechanism in the language. On the one hand, the context may help indicate a referent sufficiently; on the other hand, great precision is often not necessary or even desirable. (21) is an example:

(21) han \% hyra \% en del av v-villa me dom andra. och \% vi laga mat tillsammans. \% de e rolit tror ja.

'he rent[ed] a part of [a] house with the others. and we cook[ed] food together. that is [/was] fun I think.' (C1-6)

Here the thing that is 'fun' may be interpreted variably as 'to cook food', 'to cook food together', 'that we cooked food together', or even 'that we cooked food together in his house'. But precise reference is not important here, where 


\section{Inge Bartning and Björn Hammarberg}

the main point with the utterance de e rolit tror ja is to express an attitude to the event in question.

Using ce/det to substitute for more careful reference has the advantage of simplicity and convenience. Another illustrative example of this vague, simple reference even in native speaker speech is (2a) above, which we repeat here for convenience:

a. (Topic: How to get along with Swedes compared to Brazilians) avec les Suédois c'est un peu difficile le contact [...] parfois [...] c'est plus difficile qu'avec les \# c'est pas latin [ = les Suédois ne sont pas latins] (RIRE) mais euh il y en a beaucoup très très gentils. (I:mm)

'it's more difficult with the \# it's (= the Swedes are) not Latin (LAUGHTER) but there are many who are very very nice' (NS: Françoise)

For learners, the celdet substitute may also be a means to avoid difficult morphology or uncomfortable sentence formulation as illustrated in (22)-(24) below:

la femme c'est content. (= la femme (elle) est contente)

'the woman it's satisfied (= the woman (she) is satisfied)' (Beg: Carin, BD)

les mots c'est eh très très difficile.

(= les mots (ils) sont très très difficiles)

'the words it's euh very very difficult (=the words they are ...)' (Beg: Carin Int1)

I: qu'est-ce que tu prends comme moyen de transport pour aller à Stockholm?

'what do you take as transport means to go to Stockholm?

E: ah c'est Roslagsbanan [= je prends Roslagsbanan or c'est R. que je prends]. c'est un vieux train / un vieil train (I:mm).

'ah it's Roslagsbanan [=I take Roslagsbanan / It's R. that I take] it's an old train / an old train' (Uni: Eva Int 1)

In the structures under B (Structures 12-16) where ce/det is either non-referential or cataphoric, a different mechanism does the job. The entity spoken about is made clear in the coming utterance, and the introducing ce/det (or c'est/det $\ddot{a r}$ ) serves as a forward pointer. Note that there is an affinity between backwardpointing (anaphoric) and forward-pointing constructions. An anaphoric construction (especially one with vague reference) can often be changed into a forward-pointing one by adding specifying information in the predication fol- 
lowing c'est/det är. Consider Example (25) which is adapted from a dialogue with the learner $\mathrm{C} 1$ :

(25) (Interlocutor's question:)

tyckte du att de va lätt att förstå henne?

'did you find it easy to understand her?'

(Alternative answers:)

a. de e lättare än att prata

'it's easier than talking'

b. de e lättare att förstå än att prata

'it's easier to understand than to talk'

In (25a) de must be interpreted as an anaphoric pronoun, referring back to the interlocutor's att förstå 'to understand'. But if the pertinent information is supplied in the following context, as in (25b), the role of de switches to that of a forward-pointing dummy subject. Note that this latter construction is usually more explicit than the corresponding anaphoric construction; in fact the choice between a backward-pointing and a forward-pointing construction is an important way of regulating the degree of explicitness in cases like this and handling the balance between parsimony and clarity in formulation. The neutral pronoun itself loses or takes on a referring role accordingly. This contributes to the great flexibility of the collocation c'est/det är.

A forward-pointing $c e$ (c'est) or det (det är) gives rise to a number of syntactically complex constructions such as Existential, Anticipating, Right Dislocation and Cleft. It is of interest to find out how often such 'non-canonical' or 'marked' sentence constructions with c'est/det är are actually used by the native speakers and the learners, and when the learners start making use of them. We noted above that the Swedish learners of French sometimes overgeneralize the use of c'est where standard French has il est or il fait (Type 12) or il y a (Type 13). We interpret this as the combined effect of the fact that (a) Swedish has det är in these cases, and (b) c'est is so widely applicable in other, comparable sentence constructions in French - a case that supports Andersen's 'Transfer to Somewhere' principle. According to this principle, transfer from L1 occurs to a significant degree

if and only if (1) natural acquisitional principles are consistent with the L1 structure or (2) there already exists within the L2 input the potential for (mis-)generalization from the input to produce the same form or structure. (Andersen 1983: 182 ; italics in original)

The third group in our taxonomy, C, comprises Cases (17)-(19) where a formulation break of some sort occurs after c'est/det är, followed by an iteration, a reformulation, or the abandonment of the current utterance. These types are interesting because they are the most obvious cases that suggest a role for 
c'est/det $\ddot{a}$ as a unit in formulation and shed light on the process of building utterances. We will discuss this matter in greater detail in a following section. For the present, we may just note that these phenomena are not limited to learner speech, but occur freely with native speakers as well. Thus, whether or not it is due to limited formulation proficiency that learners produce breaks in these cases, they here apply a method of building utterances which is also characteristic of native speakers' production.

As one of our referees pointed out, researchers have noted that natural learners of French L2 use the expression / $\mathrm{se} /$ as a general predication in an early interlanguage system where they just have /se/ (=c'est 'it is or there is'), /jal (= il y a 'there is') and /janal (il n'y en a pas 'there is not') as verbal predications (see, e.g., Véronique 1994 and Trevise 1986: 372: ils /se/ très contents $=$ 'they are very pleased'). These researchers have proposed to analyse /se/ as an unanalysed sequence without the possibility to interprete it as containing a target-like cataphoric or anaphoric element. We have been aware of this analysis (see Bartning 1997c) and considered it for our data, but found that our learners of French do not seem to acquire such a system (for an exception, see however Example 22). Since all of them have participated in language courses, they are exposed to both oral and written input and readily perceive and learn morphology. This of course does not prevent learners from relying on a simple use of c'est at a beginner stage. Several beginners already use not only c'est but also il est, ils sont. They do not acquire a communicatively developed language without bound morphology. Furthermore they use the structure $X$, c'est $Y$ already as beginners (see Table 4, below). In our study this sequence is analysed as a target-like left dislocation, in view of the very frequent use of the same structure in NS speech.

\subsection{The quantification of usage in the corpora}

4.2.1. Quantitative analysis of c'est. The distribution of the French constructions with c'est is shown in Tables 1-4 below, namely the use by the native speakers (Table 1), the university beginners, the secondary school students and the first term university students (Table 2). Table 3 presents the longitudinal development of c'est-structures by one beginner in five consecutive interviews. Table 4, finally, shows the longitudinal development in five consecutive interviews by four beginners during ten months.

As Table 1 shows, the native speakers use all the c'est-structures identified in our corpora by the taxonomy, except, of course, Structures 6, 8, 12 and 13 which do not exist in French. However, the Structures 12 and 13 are presented in all tables since they are used by Swedish learners of French.

The NS have an interesting distribution in their use: Structures $1: 1$ and 2 are the most frequent ones (16.3\% and $16.0 \%$, respectively) but other structures 
Table 1. Quantitative distribution of c'est in the interviews of four native speakers

\begin{tabular}{|c|c|c|c|c|c|c|c|}
\hline & & Anne & Mél & P.-N. & Françoise & Total & $\%$ \\
\hline $1: 1$ & C'est+NP & 16 & 15 & 14 & 16 & 61 & 16.3 \\
\hline $1: 2$ & with relative & 2 & 1 & 4 & 1 & 8 & 2.1 \\
\hline 2. & C'est+Adj & 16 & 19 & 7 & 18 & 60 & 16.0 \\
\hline 3. & C'est+Adv/PP & 7 & 5 & 8 & 8 & 28 & 7.5 \\
\hline 4. & C'est+Inf & - & - & 1 & - & 1 & 0.3 \\
\hline 5. & C'est+Subcl & 5 & 1 & 1 & - & 7 & 1.9 \\
\hline 7. & ‘Tough’ const. & - & - & - & 2 & 2 & 0.5 \\
\hline 9. & Left disloc & 12 & 9 & 10 & 19 & 50 & 13.4 \\
\hline 10. & Pseud.cleft & 1 & - & 1 & 2 & 4 & 1.1 \\
\hline 11. & Term.Subcl. & 1 & 1 & - & - & 2 & 0.5 \\
\hline$* 12$ & Impersonal & - & - & - & - & - & - \\
\hline$* 13: 1$ & Existential & - & - & - & - & - & - \\
\hline $13: 2$ & with relative & - & - & - & - & - & - \\
\hline 14. & Anticipating & 16 & 8 & 4 & 7 & 35 & 9.4 \\
\hline 15. & Right disloc & 2 & 2 & - & 2 & 6 & 1.6 \\
\hline 16. & Cleft & 1 & 1 & 1 & 2 & 5 & 1.3 \\
\hline 17. & C'est+rep & 5 & 5 & 15 & 18 & 43 & 11.5 \\
\hline 18. & C'est+refor & 10 & 11 & 6 & 8 & 35 & 9.4 \\
\hline 19. & C'est+aban & 9 & 5 & 8 & 5 & 27 & 7.2 \\
\hline \multicolumn{2}{|l|}{ Total } & 103 & 83 & 80 & 108 & 374 & 100 \\
\hline \multicolumn{2}{|c|}{ Text size } & 3808 & 3855 & 3162 & 2779 & 13604 & 99.9 \\
\hline \multicolumn{2}{|c|}{$\%$ of text } & 2.7 & 2.2 & 2.5 & 3.9 & 2.7 & \\
\hline
\end{tabular}

Note: The structures marked with $*$ do not exist in standard French, but examples of these cases do occur with learners in the subsequent tables.

such as Left dislocation (Structures 9, 13.4\%), Anticipating (Structures 17, $9.4 \%$ ), repeated c'est (Structures 17, 11.5\%) and reformulated c'est (Structures $18,9.4 \%$ ) also attract many occurrences in NS speech. All these structures attract around $10 \%$ or more of the total numbers.

As Table 2 shows, the NNS do not use all the categories of c'est-structures but typically those which are most frequent in NS speech, namely Structure 1:1, 2 and 17. Beginners, e.g., only use seven out of the 15 French structures (plus one non-native structure, Structure 13:1) in their first interviews (Table 2). This tendency is confirmed by all the other 16 NNS in their first interviews: the most frequent structures are always the same, namely Structures 1:1, 2 and 17.

This state of affairs may be explained by several factors.

- Interlanguages often reflect target language frequency relations (Ellis 2002: 


\section{Inge Bartning and Björn Hammarberg}

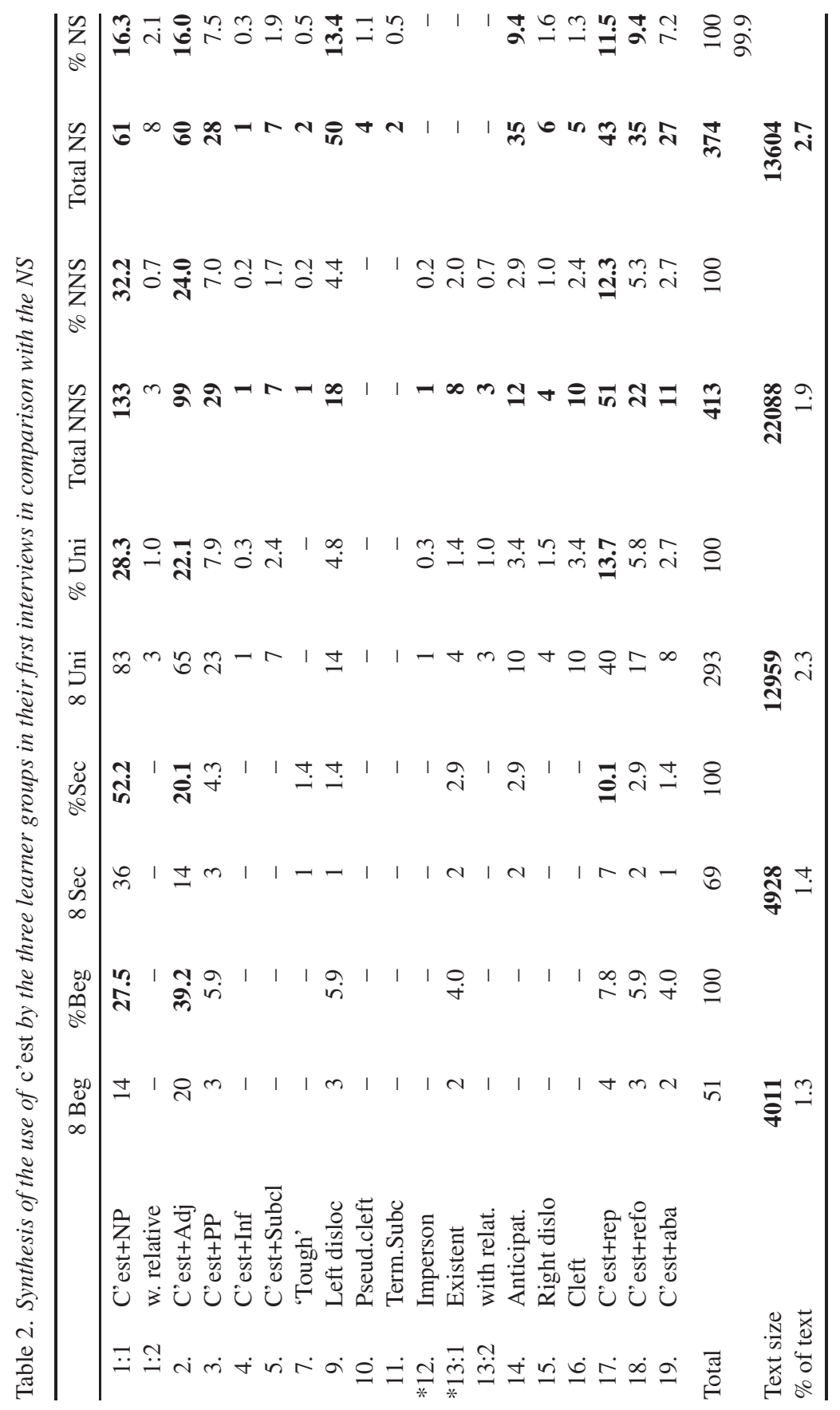


166, 179; Andersen and Shirai 1994), maybe in particular structures that are learnt as holistic chunks.

- The most frequent structures are also the syntactically most basic and simple ones which also are easier to acquire. Since they are more frequent, exposure is richer; the reason why they are frequent is that they are useful and easy to handle. The NNS early grasp the syntactically most basic/simple structures (Structure 1:1, 2, 3 in Tables 2-3). It is not until later that learners expand structures to more elaborate ones as 1:2 and 16 (Table 2, Uni. students).

- These 'early' structures, proportionally more frequent in NNS speech than in NS speech (NNS: Structure 1: $32 \%$, Structure 2: $24 \%$, NS: Structure 1 $16.3 \%$, Structure 2: $16 \%$, Tables 1-2) substitute for other more complex and elaborated structures as already mentioned: Structure 1 c'est NP is sometimes a simplified structure to dodge choices of lexical verbs, subject pronoun and verb morphology, see example (24) above; Structure 2 c'est Adj is used to avoid choices of subject pronoun, gender and agreement with predicative adjectives as in examples (22) and (23) above; this tendency explains the high percentage of Structures 1:1 and 2 in NNS speech (cf. Tables 2-4). This tendency reflects the possibility of vague reference of $c e / d e t$.

- Structures 17 and 18 are also used early. They reflect c'est as a remarkable utterance starter since it offers so many possible ways of continuing the utterance. These structures are frequent both in NS and NNS productions (Table 2). It can also reflect a search for lexis and morphology as mentioned above (cf. Towell et al. 1996; Raupach 1984). Another interesting phenomenon reflected in the data and captured by the taxonomy is the following: the Structures 1: 2, 4, 5, 7, 10 and 11 are syntactically more complex than Structures $1: 1,2$ and 3 since they contain a subordinated or nominalised clause. Structures 14-16 also represent more complex syntactic structures. Our data show that the relatively complex structures are also used and learnt late in the development of c'est: in the first interviews of the beginners and the college students there are no instances of Structures 4, 5, 10, 11, 15, 16, just one example of 7 and two examples of 14 (Table 2).

Table 2 clearly shows that the university students are the only learners to use complex syntax as represented by Structures 1: 2 (with relatives), 4, 5 (with subclauses), 13: 2 (with relatives), 15 (Right dislocation) and 16 (Cleft). Two of the structures are not used by any learner, namely Structure 10 (Pseudocleft) and 11 (Terminal Subclause), only by the NS. The university students use Structure 10 in later interviews, as in example (10b) above, taken from Lena's third interview (cf. Bartning 1997b). In the InterFra corpus it is only the university learners who are seen to expand $c^{\prime} e s t N P$ with a relative clause as in Structure 1:2 and 13:2 or who use Structure 16 (Cleft sentences; one exception). Evidence that syntactically more complex utterances (with subordination) are late developmental features in an IL is given elsewhere by Wolfe- 
Table 3. Longitudinal distribution of c'est in five interviews during ten months by the beginner Robert

\begin{tabular}{|c|c|c|c|c|c|c|c|c|}
\hline & & Int 1 & 2 & 3 & 4 & 5 & Total & $\%$ \\
\hline $1: 1$ & C'est+NP & 1 & 8 & 5 & 12 & 4 & 30 & 22.4 \\
\hline $1: 2$ & with relative & - & - & - & - & - & - & - \\
\hline 2. & C'est+Adj & - & 11 & 5 & 9 & 8 & 33 & 24.6 \\
\hline 3. & C'est+Adv/PP & - & 6 & 8 & 2 & 5 & 21 & 15.7 \\
\hline 4. & C'est+Inf & - & 1 & - & - & - & 1 & 0.7 \\
\hline 5. & C'est+Subcl & - & - & - & - & 1 & 1 & 0.7 \\
\hline 7. & 'Tough'const & - & - & - & - & - & - & - \\
\hline 9. & Left disloc & - & - & - & - & - & - & - \\
\hline 10. & Pseud.cleft & - & - & - & - & - & - & - \\
\hline 11. & Term.Subcl. & - & 1 & - & - & - & 1 & 0.7 \\
\hline$* 12$. & Impersonal & - & - & - & - & - & - & - \\
\hline$* 13: 1$ & Existential & - & 1 & 1 & - & - & 2 & 1.5 \\
\hline $13: 2$ & with relative & - & - & - & - & - & - & - \\
\hline 14. & Anticipating & - & - & - & - & 1 & 1 & 0.7 \\
\hline 15. & Right disloc & - & - & - & - & - & - & - \\
\hline 16. & Cleft & - & - & - & 1 & - & 1 & 0.7 \\
\hline 17. & C'est+rep & - & 6 & 6 & 3 & 7 & 22 & 16.4 \\
\hline 18. & C'est+refor & - & 4 & 2 & 6 & 4 & 16 & 12.0 \\
\hline 19. & C'est+aban & 1 & - & 1 & 1 & 2 & 5 & 3.7 \\
\hline \multicolumn{2}{|l|}{ Total } & 2 & 38 & 28 & 34 & 32 & 134 & 100 \\
\hline \multicolumn{2}{|c|}{ Text size } & 539 & 687 & 625 & 837 & 1016 & 3704 & \\
\hline \multicolumn{2}{|c|}{$\%$ of text } & 0.4 & 5.5 & 4.5 & 4.1 & 3.1 & 3.6 & \\
\hline
\end{tabular}

Quintero et al. 1998 for written IL and Bartning and Kirchmeyer (2003), for oral L2 production. Consequently, as the longitudinal profile of the beginner Robert's use of c'est during 10 months shows, in Table 3, there are just some isolated cases of Structure 4, 11 and 16.

The longitudinal tables show that there is an explosion of $c^{\prime}$ 'est after the first interview (Tables 3,4). This indicates that c'est is hardly available for all beginners from the very start but soon after some more time and input: a learner has to have some more linguistic material available in order to use c'est. Tables 3-4 confirm the clear increase in Interview 2. Table 3 offers a longitudinal profile of one beginner, Robert. The profile confirms the discovery of $c^{\prime}$ 'est-structures in Interview 2 to the extent that Robert ventures even complex structures such as 4 and 11 and overuses c'est for il y a (Structure 13:1). In the last two interviews three of the complex structures emerge, Structures 5, 14 and 16. 
Table 4. Synthesis of five consecutive interviews by four beginners (Carin, Emelie, Jan and Robert) during ten months

\begin{tabular}{|c|c|c|c|c|c|c|c|c|}
\hline & & Int 1 & 2 & 3 & 4 & 5 & Total & $\%$ \\
\hline $1: 1$ & C'est+NP & 5 & 10 & 10 & 33 & 15 & 73 & 23.7 \\
\hline $1: 2$ & with relative & - & - & - & - & - & - & - \\
\hline 2. & C'est+Adj & 6 & 26 & 11 & 22 & 18 & 83 & 27.4 \\
\hline 3. & C'est+Adv/PP & 3 & 9 & 9 & 6 & 7 & 34 & 11.0 \\
\hline 4. & C'est+Inf & - & 2 & 1 & 2 & - & 5 & 1.6 \\
\hline 5. & C'est+Subcl & - & - & - & - & 1 & 1 & 0.3 \\
\hline 7. & 'Tough' const & - & - & - & - & - & - & - \\
\hline 9. & Left disloc & 2 & 2 & - & - & - & 4 & 1.3 \\
\hline 10. & Pseud.cleft & - & - & - & - & - & - & - \\
\hline 11. & Term.Subcl. & - & 1 & - & - & - & 1 & 0.3 \\
\hline *12. & Impersonal & - & - & 1 & - & 2 & 3 & 1.0 \\
\hline$* 13: 1$ & Existential & 2 & 1 & 2 & 3 & 2 & 10 & 3.2 \\
\hline $13: 2$ & with relative & - & - & - & - & - & - & - \\
\hline 14. & Anticipating & - & 1 & - & - & 3 & 4 & 1.3 \\
\hline 15. & Right disloc & - & 1 & - & - & - & 1 & 0.3 \\
\hline 16. & Cleft & - & - & - & 1 & - & 1 & 0.3 \\
\hline 17. & C'est+rep & 4 & 13 & 9 & 8 & 12 & 46 & 15.0 \\
\hline 18. & C'est+refor & 3 & 5 & 3 & 8 & 8 & 27 & 8.8 \\
\hline 19. & C'est+aban & 2 & 1 & 2 & 5 & 4 & 14 & 4.5 \\
\hline \multicolumn{2}{|l|}{ Total } & 27 & 73 & 48 & 88 & 72 & 307 & 100 \\
\hline \multicolumn{2}{|c|}{ Text size } & 1806 & 1797 & 1935 & 2520 & 2530 & 10588 & \\
\hline \multicolumn{2}{|c|}{$\%$ of text } & 1.5 & 4.1 & 2.5 & 3.5 & 2.8 & 2.9 & \\
\hline
\end{tabular}

4.2.2. Quantitative analysis of det är. The distribution of the Swedish constructions with det är is shown in Tables 5-8. As described earlier, the design of the Swedish and French corpora differs in some respects. To recapitulate, the Swedish data presented here were drawn from six native informants (NS, Table 5) and six learners (NNS, Table 6). The learners were all recorded in individual interviews during ten successive sessions ranging from near-zero to an advanced stage of proficiency, along a common time schedule, following the same content plan for the interviews. This forms the basis for tracing the longitudinal development for each learner as well as for the group. Thus, Table 7 gives an example of an individual longitudinal profile, and Table 8 shows the longitudinal group profile.

Two general observations can be made in studying the distribution of det $\ddot{a} r$ in the native informants (Table 5). First, the picture is very similar across the six informants, indicating a stable pattern of distribution for our NS. Second, there is a fairly great overall resemblance with the corresponding findings for 
the French NS which were displayed in Table 1 above; this indicates a high degree of cross-linguistic similarity in target language usage between French and Swedish in the area that we are dealing with.

As is the case with the French NS, there are a few structure types which dominate in frequency. The structures 1:1 (det $\ddot{a} r+\mathrm{NP}), 2$ (det $\ddot{a} r+$ Adjective), 14 (Anticipating), and 17-19 (det är followed by some type of break) are among the most frequent types, like their French counterparts. Especially the two first types have wide applicability in that they form part of very basic sentence structures and can be used freely with a large number of different nouns and adjectives; therefore their high frequency should not be unexpected. It is worth noting that the Structures 17 and 18 and, to some extent, 19, i.e., cases with a syntactic break after det $\ddot{a}$, are amply attested with all the native informants. We take this as an indication that such breaks in the utterance formulation are a regular feature of spoken discourse and cannot be taken as a criterion of incomplete mastery of the language.

Certain structure types differ markedly in frequency between the Swedish and the French NS. Left dislocation (Structure 9) is much less used in Swedish $(0.5 \%)$ than in French $(13.4 \%)$. This reflects the fact that the characteristic French use of the préambule, although available, is less utilised by the Swedish NS (cf. also Conway 2005). On the other hand, the Cleft construction (Structure 16), is more prominent in Swedish than in French speech. This reflects the fact that Cleft is a very frequent and handy foregrounding mechanism in colloquial Swedish speech. An apparent difference in frequency occurs with Existential sentences (Structure 13:1-2). These occur frequently in Swedish. But since their counterparts in native French are constructed with il y a and not with c'est, the frequency of this type in French is not reflected in the present study.

The total frequencies and the percentages for the NS have also been included in the overview of the learners' production for comparison (Table 6). To a large extent, the totals for the NNS display a similar picture to that of the NS, the most prominent structures being 1:1, 2, 14, 17 and 18 .

The fact that Structure 2, det är + Adjective, is even more prominent with the NNS ( $26.6 \%$, as compared to $17.4 \%$ for the NS), is probably because the learners during the interviews tend to utter descriptive or evaluating judgments about things more often than the native speakers do. This is also manifested in an abundance of descriptive and evaluating adjectives in the learners' utterances, such as $d y r$ 'expensive', rolig 'funny', bra 'good', svår 'difficult', möjlig 'possible', viktig 'important' and many others. Here Swedish and French learner usage reflects the same tendency.

Structure 9, det är after Left dislocation, is more common with the learners than with the native speakers ( $2.4 \%$ vs. $0.5 \%)$. On the other hand, the emphatic Cleft construction (Structure 16) is less used by the learners than by the native speakers $(2.0 \%$ vs. $8.2 \%)$. This differs markedly from the French 


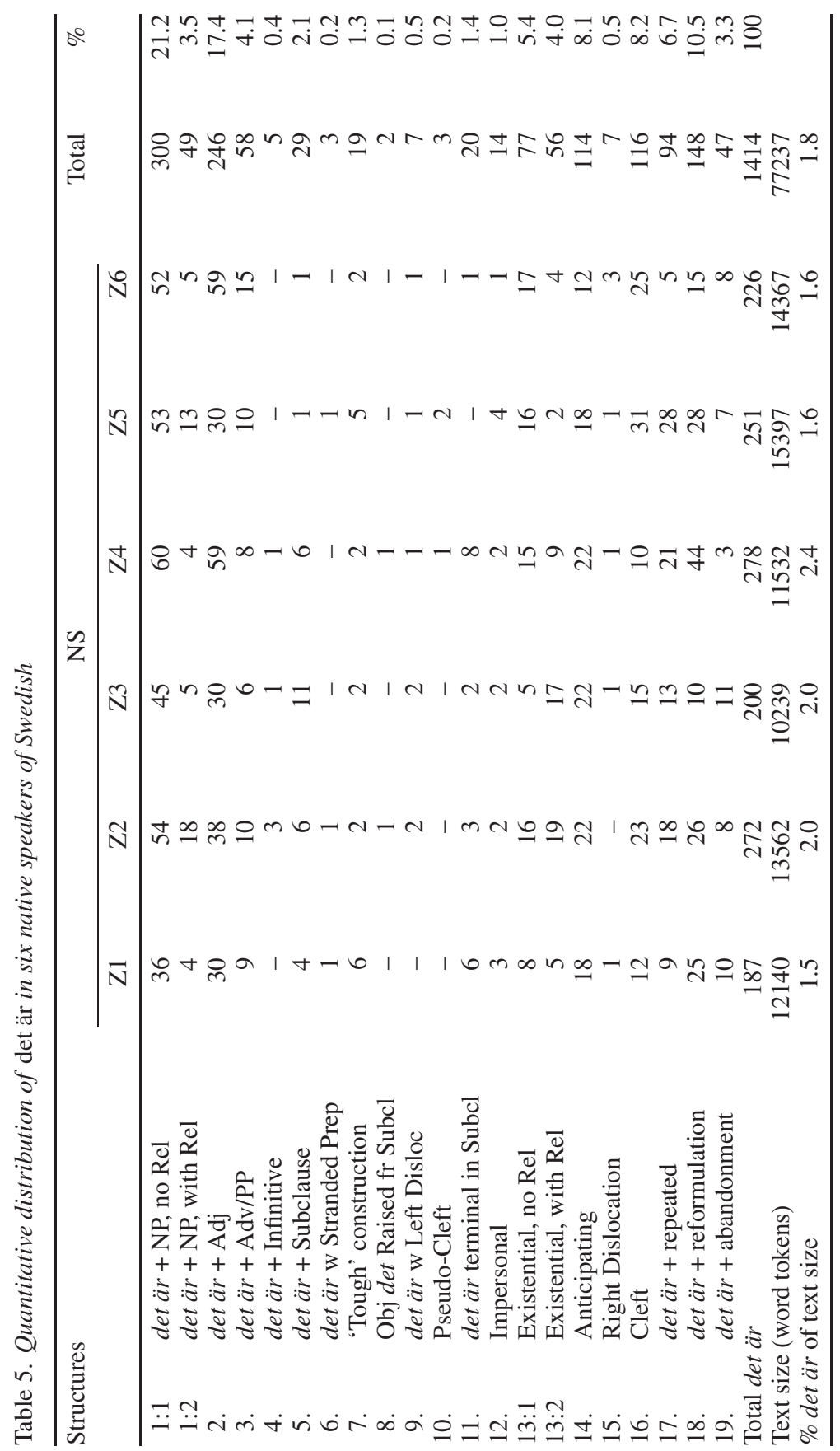




\section{Inge Bartning and Björn Hammarberg}

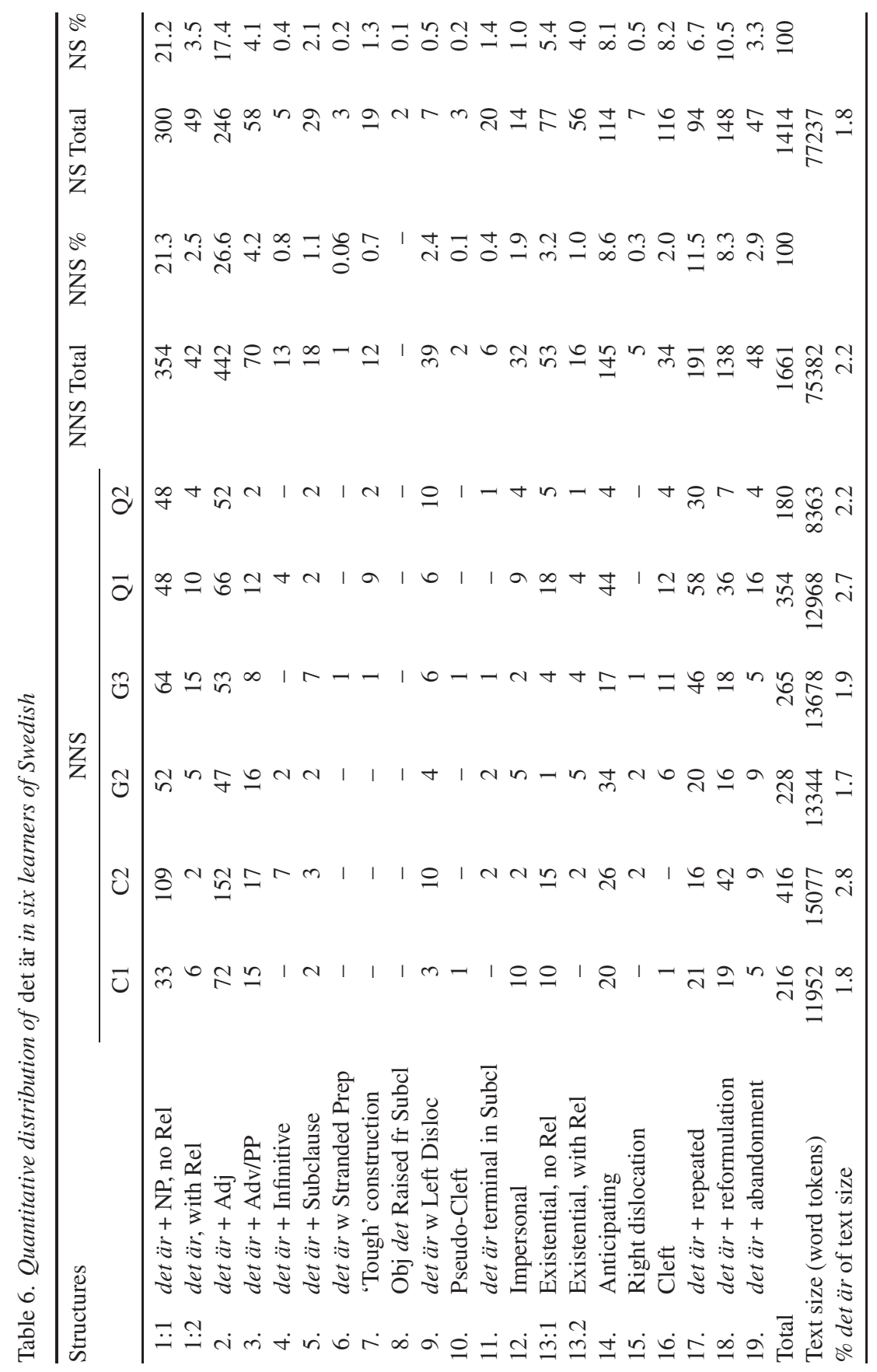


pattern. Like Left dislocation, Cleft is an optional foregrounding mechanism. Existential sentences with det är (Structure 13:1-2) are also less used by the learners. To some extent this can be accounted for by a certain overrepresentation at early stages of the near-synonym det finns 'there is/there exists'.

A developmental picture appears if we look at the quantitative profile over time for each structure. An example of such a longitudinal overview for one individual learner, $\mathrm{C} 1$, is given in Table 7. Similar profiles have been obtained for the other five learners, but are left out here for reasons of space. They add up to a combined developmental profile for the group of six learners as shown in Table 8

As Table 8 shows, the polyfunctionality of det är develops gradually in the learners' production. At the very initial stage, in Session 1, det är occurs only in simple sentences followed by NP (Structure 1:1 and the existential Structure 13:1). But by Session 2 already, 12 of the 21 structure types (counting subtypes of 1 and 13) have appeared. By Session 6, 17 structure types are present, and by the end of the observation period, in Session 10, 20 types. Both anaphoric and non-referential use of det are represented early on. The learners' overall use of det är increases over time, as can be seen in the bottom row of the table. Det är becomes gradually even more frequent with the learners than with the native speakers. The amount of det är counted in the learners' total text mass is $2.2 \%$ vs. $1.8 \%$ for the NS. The mean value for the last five sessions is as high as $2.4 \%$, i.e. one instance of det är per 42 text words on average.

Syntactic breaks after det är (Structures 17-19) occur regularly with all learners and, as Table 8 shows, they increase rather than decrease with higher proficiency. This supports our conclusion that these uses of det är are normal discourse phenomena; apparently the learners gradually reach stages of utterance complexity and fluency where these features become a regular part of discourse performance.

Whereas these various observations permit the general conclusion that det är soon becomes established as a favoured collocation in the speech of our learners, there is on the other hand also a striking difference between structures which tend to appear early in the learners' production and structures which appear later, if at all. Thus, structures with anaphoric det $+\ddot{a} r+\mathrm{NP}$, Adjective, Adverb or PP (Structures 1:1, 2 and 3) occur earlier than, e.g., det är + Infinitive (Structure 4), det är with Stranded Preposition (Structure 6), Raised Object det (Structure 8, not occurring), Pseudo-Cleft (Structure 10), or terminal det $\ddot{a r}$ (Structure 11). Among the structures with non-referring or cataphoric det, Impersonal, Existential and Anticipating constructions (Structures 12, 13:1 and 14) appear earlier than Right Dislocation and Cleft (Structures 15 and 16). Such differences in time of development are especially obvious if we compare related structures, such as 1:1 vs. 1:2, 9 vs. 10 , or $13: 1$ vs. 13:2, structures which differ essentially by the absence or presence of an embedded relative 


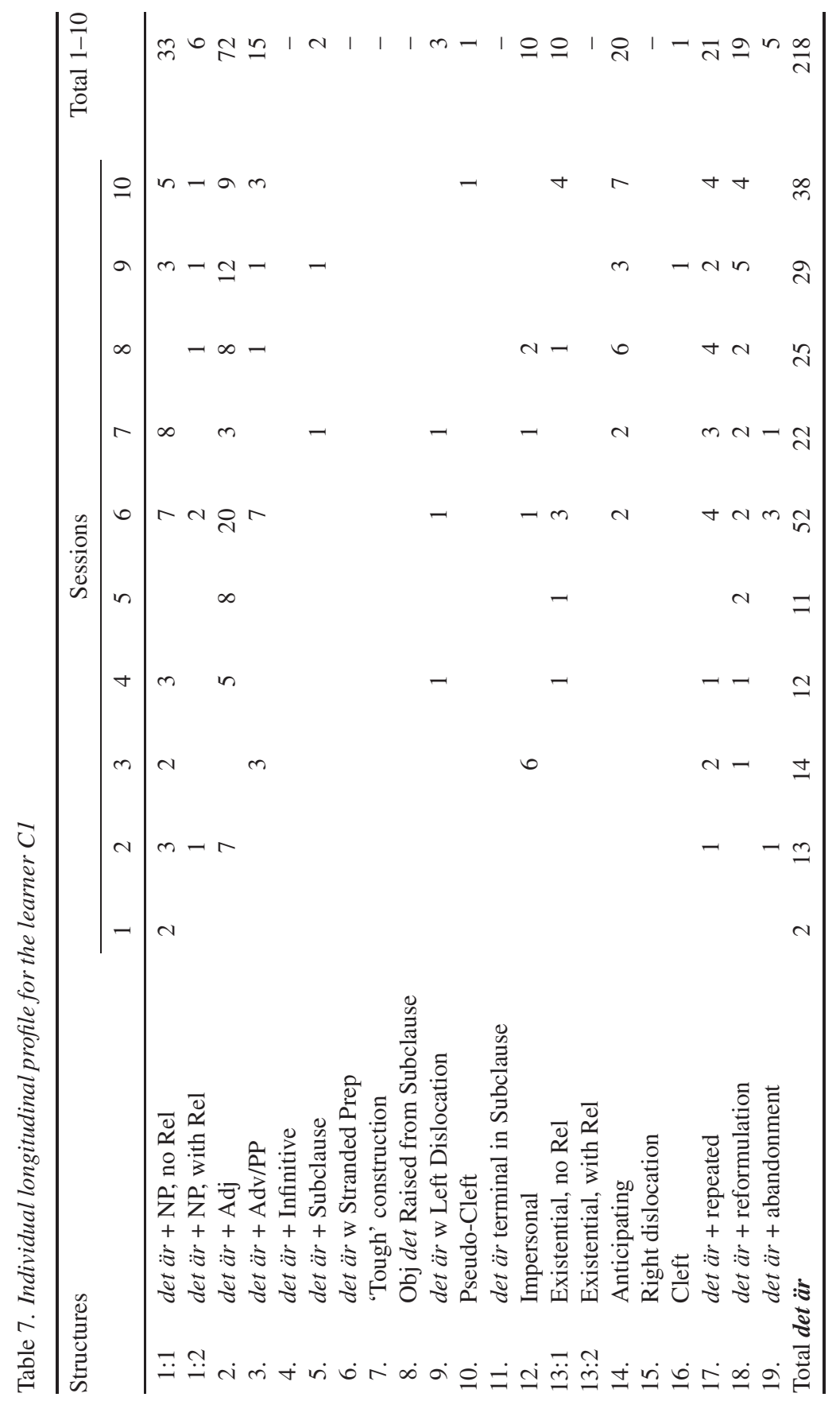




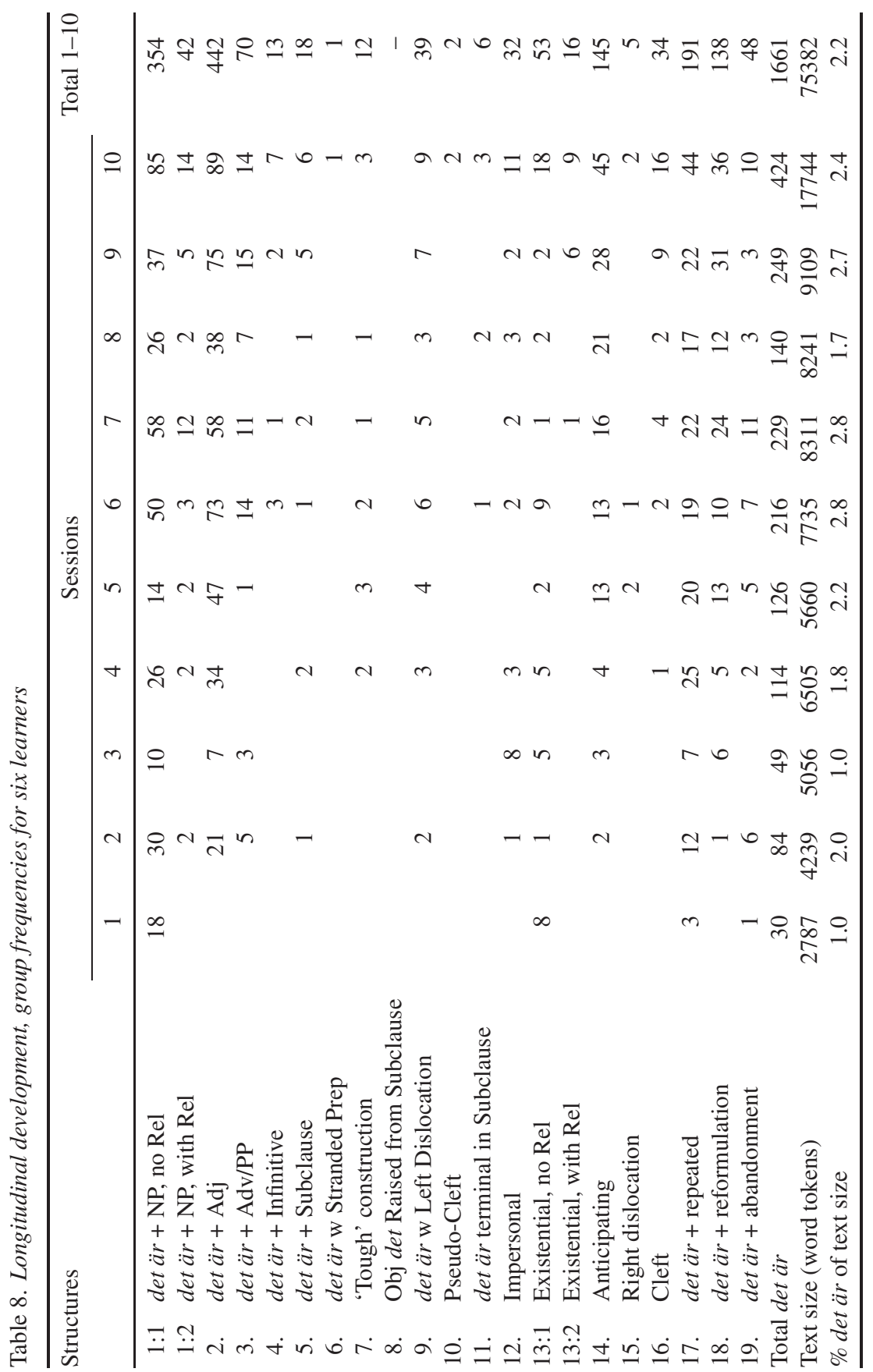




\section{Inge Bartning and Björn Hammarberg}

clause. The degree of syntactic complexity evidently tends to have the same effect here as with the Swedish learners of French. Comparing early and late structures in Table 8, we can see a correlation between total frequency and time of appearance, the tendency being that those structure types which we have noted as less frequent in the speech of native speakers and learners, are seen to develop later in the learners' observed production. The difference between early and late structures is also evidenced by the number of learners who have started using the structure in question, as a comparison with Table 6 shows. Whereas those structures which we characterised as early are used by all the learners, the late ones are attested only with some.

In a comparison of the developmental data for the Swedish and French learners (Tables 2, 3, 4 for French, 6, 7 and 8 for Swedish), the distribution of early and late structures turns out to be similar to a fairly large extent. Common features are the early appearance of Structures 1:1, 2, 3, 9, 13:1, 17, 18 and 19, and the later emergence especially of Structures 4, 5, 10, 11, 13:2, 15 and 16. Structures 6 and 8, which are not possible in French, are "late" in Swedish, as evidenced by a single late instance of 6 and no occurrence of 8 . Structures 12 and 13 are also cases where the two languages differ, and it is interesting to observe what happens here. These structures occur regularly in NS Swedish and appear early with the learners of Swedish; and despite the fact that NS French does not use c'est in these cases, constructions with c'est do occur with the Swedish learners of French. It may well be that the tendency for these structures to be carried over to learner French is favoured by their central role in Swedish L1 usage.

\section{C'est and det är in utterance production}

In the foregoing sections, we have dealt with the collocations c'est and det $\ddot{a r}$ from grammatical and quantitative-developmental points of view. In this section, we want to add the aspect of utterance production. In particular, we will consider the the connections between the grammatical flexibility, the high frequency and the role of c'est/det är in the real-time process of forming utterances.

Kempen and Hoenkamp (1987) put forward the notion of incremental processing of utterances, a notion which also constitutes a central principle in Levelt's (1989) 'Speaking' model. Although utterances while being produced are assumed successively to run through the steps of conceptualising, formulating and articulating, the three sub-processes are thought to work in parallel, so that parts of the utterance are delivered continously for the next processing component to start working with in the meantime. This serves the quick and fluent production of speech by allowing the utterance to get going while the speaker is planning how to complete it. The frequent occurrence of $c^{\prime} e s t / d e t$ 
$\ddot{a r}$ as an introducer to various predications suggests that this collocation is a favoured standard sequence to make use of as a starter and an aid in the ongoing sentence-planning.

We believe that the developmental patterns which we demonstrated in Section 4 above can best be understood in the light of a usage-based conception of language, a model in which linguistic representations emerge as a result of experience and gradual entrenchment as cognitive routines (Langacker 1987, 1999; Kemmer and Barlow 1999). The fact that a wide range of useful syntactic patterns in French and Swedish share the common string c'est or det är, respectively, is crucial in our case. This creates a basis for c'est and det är to become established in the language-user's mind as syntactic schemas which are available and readily accessible as standard parts of many larger structures. According to a usage-based view, frequency of use plays a central role in this process, as the accumulated experience of repeated use of an item gradually leads to its entrenchment in the speaker's mind (Bybee and Hopper 2001a, b; Ellis 2002).

It is noteworthy that especially those structures with c'est and det är which are most frequent with the native speakers and the learners also tend to occur earliest in the learner corpora (see Tables 2, 3 and 4 for c'est; 7 and 8 for det $\ddot{a r}$ ). We interpret this finding as the combined effect of functionality and frequency. The high frequency of some structures with our native speakers makes it reasonable to assume that the learners experience frequent use of these structures in their linguistic input from target language speakers. Frequent exposure should favour early entrenchment of the structure in the learner. On the other hand, the frequent use in the learner's own speech also favours the routinisation of these structures. The successive routinisation of a structure gradually makes it easier to process and hence more readily available to the user. Furthermore, if frequency of use is a function of communicative needs and usefulness, as we assumed above, then the polyfunctionality of c'est/det är should be an important basis for the routinisation of sentence patterns, the most useful structure types being the most driving in this respect.

Our data suggest that c'est and det $\ddot{a} r$ are entrenched as sequences. Ellis (1996) elaborates the idea "that much of language acquisition is in fact sequence learning and that abstract grammatical knowledge comes from analysis of sequence information" (Ellis 1996: 91). The learner's short-term memory recurrently analyses ordered verbal strings which are integrated in long-term memory from where they can be accessed in an automatic way. This involves chunking, "the development of permanent sets of associative connections in long-term memory" (Ellis 1996: 107).

Our findings support earlier observations in the literature that c'est and det $\ddot{a} r$ function as formulaic sequences in the ongoing planning and execution of utterances (Raupach 1984: 124; Axelsson 1988: $196 \mathrm{ff}$.). The notion of for- 
mulaic sequence (variously called formula, prefab, etc.) is usually defined in the literature on the basis of how such items are thought to be accessed. In the words of Wray (1999: 214), formulaic sequences are "stored and retrieved whole from memory at the time of use, rather than being subject to generation or analysis by the language grammar". Formulas thus serve as planning units in speech production and occur as automatised chunks. They constitute holistic processes, interacting with creative processes in utterance encoding and decoding. As Wray and Perkins (2000: 11) put it,

the best deal in communicative language processing is achieved by the establishment of a suitable balance between creative and holistic processes. The advantage of the creative system is the freedom to produce or decode the unexpected. The advantage of the holistic system is economy of effort when dealing with the expected.

Unlike other common types of formulaic items, such as lexical phrases, and set phrases used in social interaction, c'est and det är are examples of grammatical formulas. These are characterised by Erman and Warren (2000:41) as "intralinguistic text-forming items rather than units with extralinguistic reference". (For reviews of types and functions of formulas, see Raupach 1984; Weinert 1995; Erman and Warren 2000; Wray 1999, 2002; Wray and Perkins 2000; Forsberg 2006.)

One indication of formulaicity is the phonetic form which can reveal that the speaker retrieves and uses the item as a chunk. Formulaicity tends to favour a contracted or reduced form of pronunciation. C'est is always realised as a phonetically contracted unit, [se]. With det är there is a continuum of spoken variants: [de: e:, dee, de, $\mathrm{d}^{\mathrm{e}}$ ], where a more or less reduced form is what normally occurs. (The ASU corpus uses de $e$ as a broad representation of this spokenform continuum.) Coherence is obligatory, i.e., no pause is possible between $c e$ and $e s t$, nor between det and $\ddot{a} r$. Thus, repeated forms where det is followed by det är can take the shape de de $e$, or $d e=d e e$ (where ' $=$ ' is an unfilled pause), or $d e \%$ de $e$, (where '\%' is a pause-filling sound), but not $* d e d e=e$ or *de de \% e. Here det är (de e) is used as a chunk in a resumptive function after a break in the utterance. Similarly, the use of a resumptive c'est or det är is favoured in speech to form Left Dislocation and Pseudo-Cleft constructions, as in the examples under (9) and (10) above, rather than just continuing the sentence with est or $\ddot{a r}$.

Particularly revealing evidence for $c^{\prime} e s t$ and det är as preliminary starters in the planning of an utterance are those cases where c'est/det $\ddot{a} r$ is followed by a syntactic break of some sort, i.e., our Structure types 17, 18 and 19 above. As we saw, there may be repetitions, reformulations or total abandonment of the utterance, corresponding to how well the speaker manages to develop a continuation which fits with the starter c'est/det är. Such items occur as typical 
features in ongoing, coherent discourse, where the speaker is searching for formulations. Here is a Swedish example of how a speaker (the learner Q1) uses sentence-initial det är routinely in a piece of discourse while working out an answer to a question:

B: ja. hur går de till å läsa arkitektur i $i$ / på kth? 'well. how is it to study architecture at KTH?'

I: ja. de e de e väldigt spännande verkligen men också mycke jobbit. de e mycke mycke jobb. de e / man sitter där från nie till fem ( $B$ : $M H)$ varje da. (B: MHM) och de e mycke intensivt kurs. kursen e mycke intensivt.

'well. it's it's very exciting really but also very tough. there's much much work. it's / you sit there from nine to five every day. and it's [a] very intensive course. the course is very intensive.' (Q1-10)

Reformulations of various kinds (Structure type 18) are of special interest, because they show clearly how a more developed utterance is successively built up with the help of an unspecific starter c'est/det är, and thus offer insights into the gradual process of conceptualisation and formulation.

We will illustrate this with examples from NS and NNS speech of cases where c'est/det är is followed by a syntactic break and a reformulation of some kind. In Swedish, the starter may also contain an unstressed modal adverb (det är ju, det är väl, det är liksom, etc) within the same prosodic unit.

The reformulation can be a minor or a more radical one. For example, it may consist of just a shift of tense, as in (27a) or aspect, as in (27b). Even such a minimal change illustrates the formulaic use of the starter c'est or det är.
a. c'est c'était à la fois littéraire et historique.
'it's it was at the same time litterary and historical' (NS: Anne Int)
b. vi snackar tillsammans skojar tillsammans. (B: JA) de e / de blir kul när vi jobbar tillsammans.
'we chat together joke together. (B: YES) it's / it gets fun when we work together' (G3-10)

Many of the reformulations reveal the gradual build-up of an argument structure for the sentence. The speaker sets out with the provisional c'est/det är, and then elaborates the sentence with a new verb and/or a specific subject noun or pronoun. Some examples are shown in (28).

a. en même temps c'est \# ça leur permet peut-être de de de se donner de la liberté de cette façon.

'at the same time it's \# this permits them to to ot give themselves freedom in this way' (NS: Anne Int) 
b. j'aime pas le télé parce que c'est \# le télé on ne lon est toute seule avec le télé.

'I do not like television because it's \# television you not / you are totally alone with television' (Uni: Malin Int1)

c. jo men de e / ja e väldigt intresserad av ganska mycke. 'yes but it's / I'm very interested in quite a lot of things' (Z4-1)

d. I: ja tåget.

E: $j a$.

'I yes the train'

'yes.'

I: $\quad$ men lastbile+ de e också / man kan kombinera tåg å lastbil

'but the lorry it's also / you can combine train and lorry' (C2-8)

Other common types of modifying the det är clause are topicalisation of a non-subject (29a-b) and embedding the clause by inserting a verb of opinion $(29 \mathrm{c}-\mathrm{d})$ :

a. ja de $\boldsymbol{e} /$ ibland $=\boldsymbol{e}$ de $=$ orättvist tror ja.

'yes it's / sometimes = it's = unfair I think.' (C2-9)

b. ja tycker att de e / på nå sätt / ur moralisk synvinkel så e de väl ganska så förkastligt

'I think that it's / in a way / from a moral point of view I suppose it's rather objectionable' (Z1-3)

c. ja precis. de e /ja anser att de e så. 'yes precisely. it's / I think that it's so.' (G3-8)

d. ah oui à l'université oui c'est bien / c'est \# je crois que c'est onze livres / en français.

'ah yes at the university yes it's OK / it's \# I think that it's eleven books in French' (Uni: EvaInt1)

An interesting case of French c'est as a starter is the switch from c'est to il $y$ $a$, especially in learner discourse, but quite regular also in native speech. It is not only il y a but also other impersonal constructions with $i l$ as formal subject that follow after the c'est starter even in native speech:

(30) a. quand j'habitais à Val de Loire c'est \# il y a beau- / il y avait beaucoup de: de vin / qui sont bien. (I:mm)

'when I lived in the Loire Valley it is \# there was much / there was much wine which was good.' (Uni: Eva Int1)

b. l'hiver c'est \# il fait quinze degrés donc.

'in winter it's \# it's fifteen degrees thus' (NS: Françoise Int) 
c. c'est c'est \# il faut faire attention quand on est en voiture. 'it's it's \# you have to be careful when you are in a car' (NS: Françoise Int)

As we can see from the examples in (27), (28), (29) and (30), c'est/det är tends to be used as a general point of departure in working out a message. In some cases, such as $(27 \mathrm{a}-\mathrm{b})$, the reformulation limits itself to a relatively minor change. But in other instances, the sentence is restarted in a more radical way, suggesting that essential parts of the conceptual information for the remaining utterance were not yet available at the point of the break. Sometimes a fundamentally different plan is devised for the continued utterance, and the schema c'est/det är is discarded. In many cases, however, there seems to be a tendency to keep the schema $c^{\prime}$ est/det $\ddot{a} r$, at least in part, when working out the rest of the utterance.

\section{Conclusion}

In this study of functionality, formulation and frequency, we have chosen to focus, in each of two languages, on a collocation which is extremely polyfunctional as a component in different grammatical constructions, plays a significant role as a formula in the planning and execution of utterances, and has a characteristic distribution of frequency of use. We have tried to show how these properties are connected to each other, and how they together have a bearing on the development of learners' interlanguages. In a sense we have taken an opposite point of view compared to what has been usual in second-language studies, when we have chosen not to look at more difficult or advanced phenomena which limit the learner's L2 competence, but rather to concentrate on a very central item in language usage, one that occurs all the time and is readily acquired by learners. $C^{\prime}$ 'est and det är are obviously very useful standard elements in discourse and in utterance production. It seems that speakers need the access to such standard elements for their formulation work. The acquisition and further refinement of such central linguistic means is an important part of the development of second language competence.

Stockholm University

<Inge.Bartning@ fraita.su.se> $<$ ham@ling.su.se>

\section{Appendix: Transcription conventions in the examples}

When reading the examples, please note the following differences between the InterFra and the $A S U$ practice. 


\section{The French InterFra corpus}

Source references with informant and recording session are given in parenthesis after each example; e.g.: speaker identification (group and pseudonym: Beg(inner): Carin), task and chronological number of the task: Int(erview) 1, BD 1 = 'bande dessinée' $=$ cartoon .

The letters I and $\mathrm{E}$ in the left column are speaker identifications used where the text extract contains turns from more than one speaker. Here I refers invariably to the interviewer and $\mathrm{E}$ to the (native or non-native) informant.

\begin{tabular}{ll}
\multicolumn{2}{c}{ Special symbols used: } \\
Short empty pause \\
/I & Longer empty pause \\
$\#$ & Reformulation marker \\
$?$ & Completed question \\
\langle & Completed sentence other than question \\
\langle\rangle & Around a code switch \\
(SIGH) & Non verbal sounds \\
+ & Beginning of simultaneous speech \\
SIM & End of simultaneous speech \\
() & Around interlocutor's backchannelling
\end{tabular}

\section{The Swedish ASU corpus}

Source references with informant and recording session are given in parenthesis after each example; e.g., Z4-1 = informant Z4, session no. 1; C2-6 = informant $\mathrm{C} 2$, session no. 6 . The letter code $\mathrm{Z}$ refers to native Swedish informants; the letter codes C, G and Q refer to Chinese, Greek and Portuguese learners, respectively.

The letters I, B and E in the left column are speaker identifications used where the text extract contains turns from more than one speaker. Here I refers invariably to the (native or non-native) informant in question, and $\mathrm{B}$ and $\mathrm{E}$ are the interviewers. If no such speaker identification is given, the text extract is from the informant.

Special symbols used:

$=$ Empty pause

\% Pausefiller (replaces letter notations such as "eh”, “ah”, “ööh”)

- Interrupted word

$+\quad$ Morphologically unclear ending

/ Interruption, reformulation; non-completed sentence

? completed question sentence

completed sentence other than question

<) Around a code-switch

( ) Around interlocutor's backchannelling 


\section{References}

Allwood, Jens (1999). Talspråksfrekvenser: frekvenser för ord och kollokationer i svenskt tal- och skriftspråk. (Gothenburg Papers in Theoretical Linguistics S 21.) Gothenburg university, Department of linguistics.

Andersen, Roger W. (1983). Transfer to somewhere. In Language Transfer in Language Learning, Susan Gass and Larry Selinker (eds.), 177-201. Rowley MA: Newbury House.

Andersen, Roger W. and Yasushiro Shirai (1994). Discourse motivations for some cognitive acquisition principles. Studies in Second Language Acquisition 16: 133-156.

Axelsson, Monica (1988). Helfraser och ramar - ett viktigt inslag på andraspråksinlärarens väg mot ett kreativt regelsystem. In Första symposiet om svenska som andraspråk. Vol. I: Föredrag om språk, språkinlärning och interaktion, Kenneth Hyltenstam and Inger Lindberg (eds.), 191-202. Stockholm University, Centre for Research on Bilingualism.

Bartning, Inge (1997a). L'apprenant dit avancé et son acquisition d'une langue étrangère. Tour d'horizon et esquisse d'une caractérisation de la variété avancée. AILE 9: 9-50.

- (1997b). C'est in native and non-native spoken French. In Norm, Variation and Change in Language. Proceedings of the Centenary Meeting of the Nyfilologiska Sällskapet. Studier $i$ modern språkvetenskap, vol. 11: 13-47. Stockholm: AWE International.

- (1997c). Structuration des énoncés et stratégies référentielles à l'aide de la prédication c'est $X$ chez des apprenants avancés et des locuteurs natifs. Travaux de linguistique 34: 65-90.

- (2002). La variété avancée et sa place dans les phases acquisitionnelles d'une langue étrangère. In Mélanges publiés en hommage à Gunnel Engwall, Inge Bartning, Johan Falk, Lars Fant, Mats Forsgren, Ritva Maria Jacobsson and Jane Nystedt (eds.). Acta Universitatis Stockholmiensis. Romanica Stockholmiensia 20: 1-12. Stockholm: Almqvist and Wiksell International.

- (2006). Une formule bien utile: le cas de c'est. In Aux carrefours du sens. Hommages offerts à Georges Kleiber pour son $60^{e}$ anniversaire, Martin Riegel, Catherine Schnedecker, Peter Swiggers and Irène Tamba (eds.), 175-190. Louvain: Peeters.

Bartning, Inge and Nathalie Kirchmeyer (2003). Le développement de la compétence textuelle à travers les stades acquisitionnels en français L2. AILE 19: 9-39.

Bartning, Inge and Suzanne Schlyter (2004). Itinéraire acquisitionnel et stades de développement en français L2. Journal of French Language Studies 14: 281-299.

Beckman, Natanael (1934). Västeuropeisk syntax. Några nybildningar i nordiska och andra västeuropeiska språk. In Göteborgs högskolas årsskrift, Vol. 40, No. 1934/4: 1-44. Göteborg.

Blanche-Benveniste, Claire (1990). Le français parlé. Études grammaticales. Paris: CNRS.

Brown, Gillian and George Yule (1983). Discourse Analysis. Cambridge: Cambridge University Press.

Bybee, Joan and Paul Hopper (2001). Introduction to frequency and the emergence of linguistic structure. In Frequency and the Emergence of Linguistic Structure, Joan Bybee and Paul Hopper (eds.), 1-24. Amsterdam/Philadelphia: John Benjamins.

Bybee, Joan and Paul Hopper (eds.) (2001). Frequency and the Emergence of Linguistic Structure. Amsterdam/Philadelphia: John Benjamins.

Conway, Åsa (2005). Le paragraphe oral en français L1, en suédois L1 et en français L2. Étude syntaxique, prosodique et discursive. Études romanes de Lund 73. PhD thesis. Lund: KFS $\mathrm{AB}$

Ekerot, Lars-Johan (1979). Syntax och informationsstruktur. In Svenska i invandrarperspektiv, Kennenth Hyltenstam (ed.), 79-108. Lund: Liber Läromedel.

Ellis, Nick (1996). Sequencing in SLA: Phonological memory, chunking, and points of order. Studies in Second Language Acquisition 18: 91-126.

- (2002). Frequency effects in language processing. Studies in Second Language Acquisition 24: $143-188$

Erman, Britt and Beatrice Warren (2000). The idiom principle and the open choice principle. Text 20: 29-62. 


\section{Inge Bartning and Björn Hammarberg}

Forsberg, Fanny (2006). Le langage préfabriqué en français parlé L2. Étude acquisitionnelle et comparative. Ph.D. Thesis. Stockholm University, Department of French, Italian and Classical Languages.

Fraurud, Kari (1992). Processing noun phrases in natural discourse. PhD thesis. Stockholm University, Department of Linguistics.

- (2000). Demonstrativer i svensk sakprosa. In Denna - den här - den där. Om demonstrativer $i$ tvärspråklig belysning. En minnesskrift till Elsie Wijk-Andersson. Special issue of ASLA Information 26 (2): 5-28. Uppsala: ASLA [Association Suédoise de Linguistique Appliquée].

Fraurud, Kari and Christina Hellman (1999). Abstract objects: Transitional discourse referents. Paper presented at the 6th International Cognitive Linguistics Conference, 10-16 July 1999, Stockholm. (Quoted from handout.)

Gadet, Françoise (1989). Le français ordinaire. Paris: Colin (2nd ed. 1997)

Hammarberg, Björn (1999). Manual of the ASU-corpus, a longitudinal corpus of adult learner Swedish with a corresponding part from native Swedes. Department of Linguistics, Stockholm University.

- (2000). A polyfunctional word in native usage and L2 acquisition: the Swedish pronoun 'det'. In Kontraster i språk, Johan Falk, Gunnar Magnusson, Gunnel Melchers and Barbro Nilsson (eds.), 103-129. Stockholm: AWE International.

Hammarberg, Björn and Åke Viberg (1977). The place-holder constraint, language typology, and the teaching of Swedish to immigrants. Studia Linguistica 21: 106-163.

Hancock, Victorine (2000). Quelques connecteurs et modalisateurs dans le français parlé d'apprenants avancés. Étude comparative entre suédophones et locuteurs natifs.Cahiers de la recherche 16. Stockholm University. Ph.D. thesis.

Holmes, Philip and Ian Hinchliffe (2003). Swedish: A Comprehensive Grammar. 2nd ed. New York: Routledge

Kemmer, Suzanne and Michael Barlow (1999). Introduction: A usage-based conception of language. In Usage-Based Models of Language, Michael Barlow and Suzanne Kemmer (eds.), vii-xxvii. Stanford: CSLI Publications, Center for the Study of Language and Information.

Kempen, Gerard and Edward Hoenkamp (1987). An incremental procedural grammar for sentence formulation. Cognitive Science 11: 201-258.

Langacker, Ronald W. (1987). Foundations of Cognitive Grammar. Vol. 1: Theoretical Prerequisites. Stanford: Stanford University Press.

- (1999). A dynamic usage-based model. In Usage-Based Models of Language, Michael Barlow and Suzanne Kemmer (eds.), 1-63. Stanford: CSLI Publications, Center for the Study of Language and Information.

Levelt, Willem J. M. (1989). Speaking: From Intention to Articulation. Cambridge MA: The MIT Press.

Morel, Mary-Annick and Laurent Danon-Boileau (1998). La grammaire de l'intonation. L'exemple du français. Paris: Ophrys.

Olsson, Hugo (1986). La concurrence entre il, ce, cela (ça) comme sujet d'expressions impersonnelles en français contemporain. Acta Universitatis Umensis 71. Stockholm: AWE International.

Pedersen, John, Ebbe Spang-Hanssen and Carl Vikner (1982). Fransk universitetsgrammatik. Stockholm: Esselte Studium.

Raupach, Manfred (1984). Formulae in second language speech production. In Second Language Productions, Hans W. Dechert, Dorothea Möhle and Manfred Raupach (eds.), 114-147. Tübingen: Gunter Narr.

Riegel, Martin, Jean-Christoh Pellat and René Rioul (1994). Grammaire méthodique du français, Paris: PUF.

Sundman, Marketta (1980). Existentialkonstruktionen i svenskan. Publications of the Research Institute of the Åbo Akademi Foundation, 57. Åbo.

- (1987). Subjektval och diates $i$ svenskan. Åbo: Åbo Academy Press. 
Teleman, Ulf, Staffan Hellberg and Erik Andersson (1999). Svenska Akademiens Grammatik. Vol. 1-4. Stockholm: Norstedts.

Towell, Richard, Roger Hawkins and Nives Bazergui (1996). The development of fluency in advanced learners of French. Applied Linguistics 17 (1): 84-119.

Trévise, Anne (1986). L'émergence et la spécification des marqueurs de prédication en langue 2. In Acquisition d'une langue étrangère : perspectives et recherches. Alain Giacomo and Daniel Véronique (eds.), 365-381, Aix-en-Provence: Université de Provence.

Weinert, Regina (1995). The role of formulaic language in second language acquisition: $\mathrm{A}$ review. Applied Linguistics 16: 180-205.

Véronique, Daniel (1994). Il y $a$ et c'est dans l'interlangue d'apprenants de français. Cahiers du français contemporain 1: 55-75. Paris: Didier Érudition.

Wolfe-Quintero, Kate, Shunji Inagaki and Hae-Young Kim (1998). Second Language Development in Writing: Measures of Fluency, Accuracy and Complexity. Honolulu: University of Hawai'i Press.

Wray, Alison (1999). Formulaic language in learners and native speakers. Language Teaching 32: 213-231.

Wray, Alison (2002). Formulaic Language and the Lexicon. Cambridge: Cambridge University Press.

Wray, Alison and Michael R. Perkins (2000). The functions of formulaic language: An integrated model. Language and Communication 20: 1-28. 